\title{
Taxonomic biodiversity of geniculate coralline red algae (Corallinales, Rhodophyta) from the Macaronesian region: summary and analysis
}

\author{
Edgar F. Rosas-Alquicira • Rafael Riosmena-Rodríguez • \\ Julio Afonso-Carrillo • Ana I. Neto
}

Received: 30 October 2009 / Revised: 17 June 2010 / Accepted: 23 June 2010 / Published online: 10 July 2010

(C) Springer-Verlag and AWI 2010

\begin{abstract}
A catalog and critical review of species and infraspecific taxa of non-fossil geniculate coralline red algae (Corallinales, Rhodophyta) previously reported from the Macaronesian region are presented along with an assessment of species diversity in the region. Published records of geniculate coralline algae are included along with comments relating to type material. Within the cata$\log$, taxa are organized alphabetically by genus and within this by final epithet. From the 31 taxa recorded, 4 are based on type collections from Macaronesian localities. The types of most species and infraspecific taxa reported from the region have yet to be re-examined in a modern context, and most Macaronesian records require verification. The biodiversity of Macaronesian geniculate coralline algae may be lower than current information indicates.
\end{abstract}

Communicated by Inka Bartsch.

E. F. Rosas-Alquicira $(\varangle) \cdot$ A. I. Neto

CIIMAR (Centro Interdisciplinar de Investigação

Marinha e Ambiental), Rua dos Bragas 289,

4050-123 Porto, Portugal

e-mail: alquicira@uac.pt

E. F. Rosas-Alquicira · A. I. Neto

Grupo de Biología Marinha, Departamento de Biologia,

Universidade dos Açores, Rua Mãe de Deus 58, Apart. 1422,

9502 Ponta Delgada, São Miguel, Açores, Portugal

E. F. Rosas-Alquicira · R. Riosmena-Rodríguez Programa de Investigación en Botánica Marina, Departamento de Biología Marina, Universidad Autónoma de Baja California Sur, Km. 5.5, Carretera al Sur. Apdo.

Postal 19-B, C.P. 23080 La Paz, México

\section{J. Afonso-Carrillo}

Departamento de Biología Vegetal (Botánica),

Universidad de La Laguna, 38271 La Laguna,

Tenerife, Islas Canarias, España
Keywords Analysis $\cdot$ Baseline $\cdot$ Corallinales $\cdot$ Geniculate . Macaronesia $\cdot$ Taxonomy

\section{Introduction}

The Macaronesian region sensu lacto includes the Azores, Madeira and Salvage Islands (Portugal), the Canaries (Spain) and Cape Verde Islands (Fig. 1). The first studies of (non-fossil) coralline geniculate red algae (Corallinales, Rhodophyta) in this region go back to the beginning of the XIX century with the paper of Lamarck (1815: 233, 237), who described Corallina millegrana and Corallina purpurata for the Canary Islands.

An important contribution to the knowledge of Macaronesian Corallinales, with an extensive collection for the region, was done by the Dutch oceanographic expeditions CANCAP, in the 1970 and 1980s, with material collected in the Azores, Madeira, Salvage, the Canaries and Cape Verde Islands (Prud'homme van Reine 1988).

Historical revisions of phycological studies including the coralline algae are those by Neto (1994) for the Azores, Levring (1974) and Neto et al. (2001) for Madeira, AfonsoCarrillo (1988) and Haroun et al. (2002) for the Canary Islands and Prud'homme van Reine (1988) for Cape Verde Islands. The accounts of the coralline algae published by Price et al. $(1986,1992)$ include information on Macaronesian material but only for Cape Verde and the Canary Islands. The work of John et al. (2004) also included data from Madeira but the Azores were not considered in any of these publications.

Currently, there are 31 names of geniculate coralline seaweeds reported for the Macaronesian region but there is no published information compiling the data from the various archipelagos. Information is also lacking on basionym, 
Fig. 1 The Macaronesian region

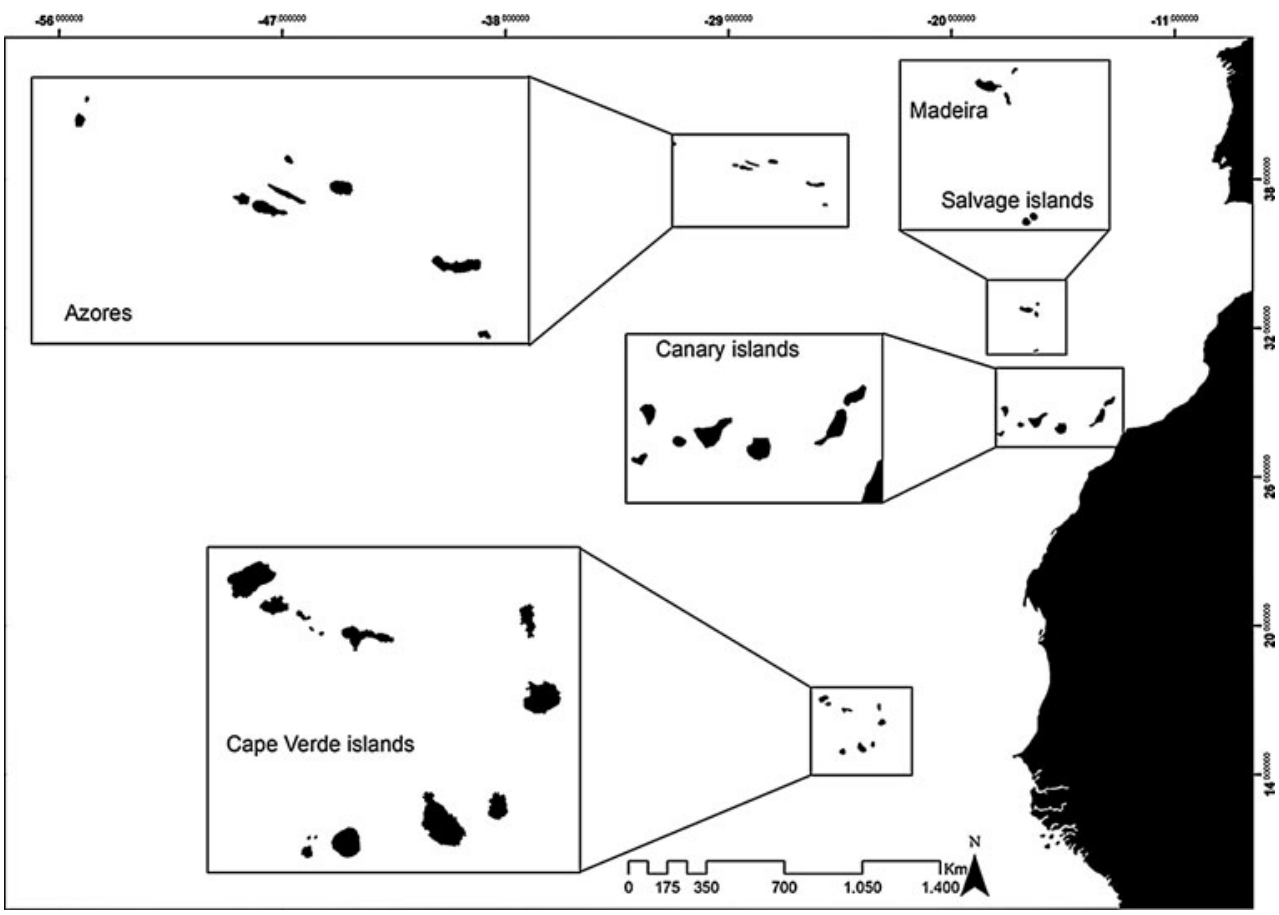

type material locality, localization, and illustrations, current nomenclatural situation and taxonomic status.

The present study provides a baseline summary and analysis of existing taxonomic information on the geniculate Corallinales for the Macaronesian region sensu lacto, along with comments and/or nomenclatural notes as required.

\section{Arrangement of the catalog}

The species records were compiled from identification keys, floristic studies, checklists and published catalogs. Unpublished theses and reports were not considered because some involved names that are not effectively published in the context of the International Code of Botanical Nomenclature (ICBN, McNeill et al. 2006).

The type material of a number of taxa of geniculate Corallinales reported from the Macaronesian region has not been studied in the modern context of taxonomy, meaning that the descriptions are incomplete and factually inaccurate, include criteria that are unreliable and are not based on original research encompassing specific morphological, anatomical and ultrastructural investigations. The presence or absence of genicula in those taxa has been inferred from the genus in which the taxon was placed originally. Thus, taxa whose types have not been studied in a modern context but that originally were described as species or infraspecific taxa of Amphiroa J. V. Lamouroux, Cheilosporum (Decaisne) Zanardini, Corallina Linnaeus, Haliptilon (Decaisne)
Lindley and Jania J. V. Lamouroux are presumed to possess genicula.

Taxa are listed in alphabetical order by the currently accepted name for the genera and constitutent species. For each taxon, the following information is provided: basionym, type material localization, type locality, published illustrations of type material, reference to its study in a modern context and current placement/name. Table 1 summarizes this information. Published records for the Macaronesian region are also provided, following a north-south latitudinal order: Azores, Madeira, Salvage Islands, Canary Islands and Cape Verde Islands. For each archipelago, homotypic synonyms are arranged in chronological order, with author citations and publications details provided for each.

In the case of taxa for which the type material is not known, or when known, was not revised, nor were the specimens studied in the modern context of taxonomy the status and/or disposition of the taxa is reported as uncertain. Family names of authors are written out in full and Herbarium abbreviations follow Holmgren and Holmgren (1998).

\section{Catalog}

Amphiroa

Currently, the genus Amphiroa is recognized as one of six genera in the Corallinaceae, subfamily Lithophylloideae (Bailey 1999, Table 4, p. 214). Presently its generic concept 


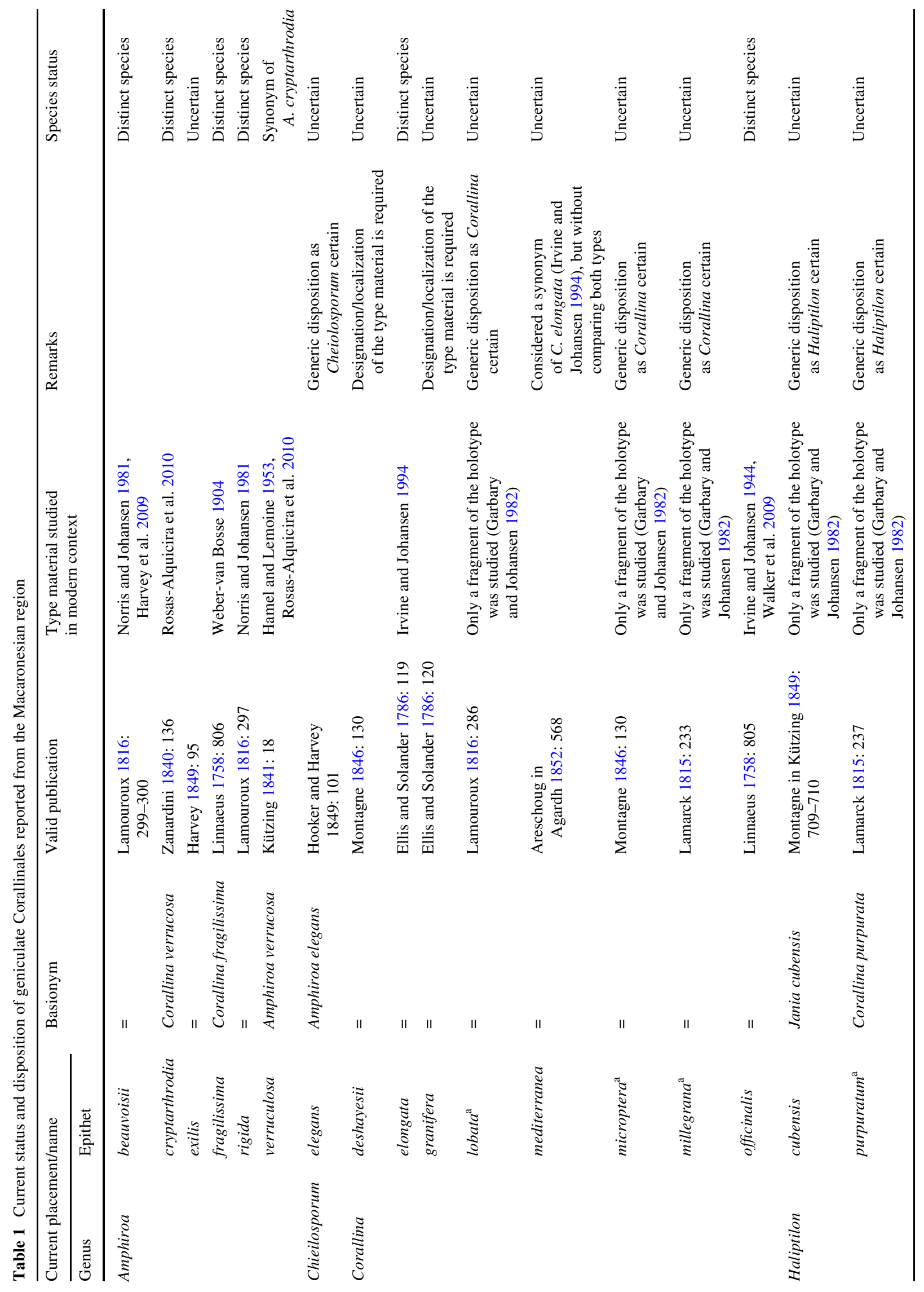




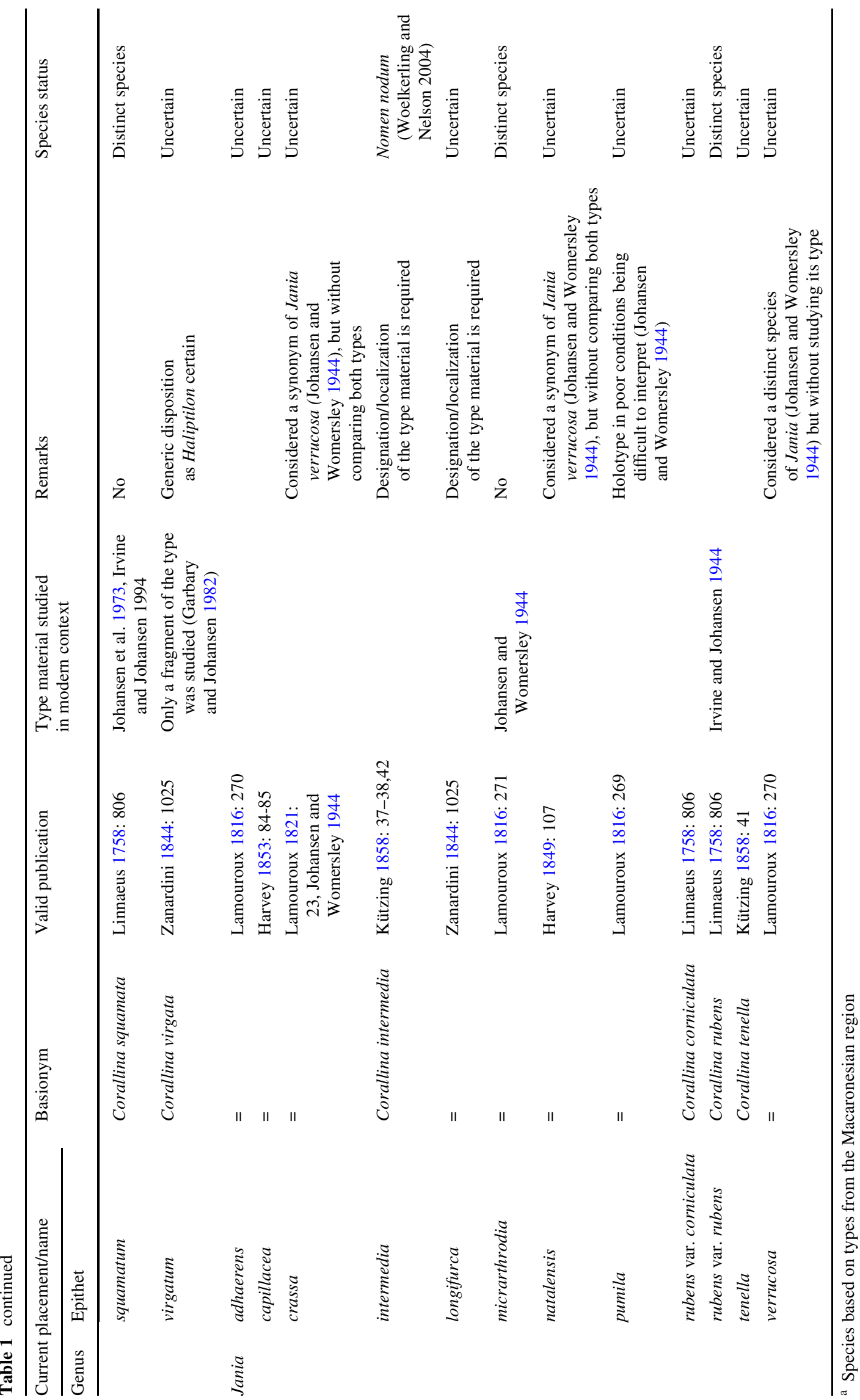


is consensual and a detailed diagnosis is provided by Womersley and Johansen (1996: 283-284) and Harvey et al. (2009: 259; Table 1, p. 260). The relationship between Amphiroa and other Lithophylloideae genera is provided in Woelkerling et al. (2002, Table 2, p. 370: Table 3, p. 372). The work by Afonso-Carrillo and Sansón (1999: 33-34) provides a key for species diagnosis in the Canaries.

\section{Amphiroa beauvoisii J. V. Lamouroux}

Basionym: Amphiroa beauvoisii J. V. Lamouroux 1816: 299-300. Holotype: CN (Norris and Johansen 1981: 6); illustrations: Norris and Johansen (1981, Fig. 7b, p. 6) and Harvey et al. (2009, Figs. 18-21, p. 270; Figs. 22-23, p. 271). Type locality: Portugal coasts (Lamouroux 1816: 299).

Current placement/name: A. beauvoisii J. V. Lamouroux according to Norris and Johansen (1981: 6) and Harvey et al. (2009: 268-273) based on the study of the holotype.

Published records:

AZORES: Gain (1914: 22), Schmidt (1931: 67), Feldmann (1946: 421), Ardré (1970: 224), CordeiroMarino (1978: 46), South and Tittley (1986: 42), Reyes and Sansón (1991: 74), Schneider and Searles (1991: 226), Neto (1994: 25), Prud'homme van Reine et al. (1994: 70), Tittley and Neto (1994: 7), Cremades et al. (1997: 13), and Rosas-Alquicira and Neto (personal observation).

MADEIRA: Levring (1974: 68), Augier (1985: 101) and John et al. (2004: 58).

SALVAGE ISLANDS: John et al. (2004: 58).

CANARY ISLANDS: Afonso-Carrillo et al. (1984: 30), Price et al. (1986: 10), Gil-Rodríguez et al. (1987: 146, 2003: 25), Viera-Rodríguez (1987: 241), AfonsoCarrillo and Sansón (1989: 26; 1999: 195), Guadalupe et al. (1995: 37), Haroun et al. (2002: 146), Sangil et al. (2003a: 87; 2004: 89) and Muñoz et al. (2007: 107).

\section{Amphiroa cryptarthrodia Zanardini}

Basionym: Corallina verrucosa Zanardini 1840: 136. Neotype: MCVE unnumbered, Zanardini's original collection nr. 14 (Rosas-Alquicira et al. 2010): illustrations: Hamel and Lemoine (1953, pl. 5, p. 43) and Rosas-Alquicira et al. (2010, Figs. 1, 4-20) as Amphiroa verruculosa Kützing; Rosas-Alquicira et al. (2010, Figs. 27-36) as Amphiroa cryptarthrodia Zanardini. Syntype localities: Trieste and Dalmazia, Adriatic Sea (Rosas-Alquicira et al. 2010).

Current placement/name: A. cryptarthrodia Zanardini according to Rosas-Alquicira et al. (2010) based on the study of neotype material. Afonso-Carrillo et al. (1983: 46) cited the presence of $A$. cryptathrodia at the Canaries as dubious.

Published records:

AZORES: Schmidt (1931: 67), Audiffred and Weisscher (1984: 17), South and Tittley (1986: 42), Neto (1994: 25), Tittley and Neto (1994: 7) and RosasAlquicira and Neto (personal observation).

MADEIRA: Levring (1974: 68), Audiffred and Weisscher (1984: 17, 33) and John et al. (2004: 58).

SALVAGE ISLANDS: Audiffred and Weisscher (1984: 17, 33), Price et al. (1986: 11) and John et al. (2004: 58).

CANARY ISLANDS: Lemoine (1929: 71), Gil-Rodríguez and Afonso-Carrillo (1980: 35), Price et al. (1986: 11) and John et al. (2004: 58).

\section{Amphiroa exilis Harvey}

Basionym: Amphiroa exilis Harvey 1849: 95. Syntypes: TCD specimens Darwin 595 (with annotation Det. H.W. Johansen Sept 1967) and Darwin 629 (two specimens), BM Darwin 595 (one sheet with the stamp of Hookerianum Herbarium 1867 and the annotation A. exilis) and Darwin 629 (with the annotation A. exilis); illustrations: Porter (1987, BM Darwin 595, Fig. 1, p. 188; BM Darwin 629, Fig. 2, p. 189). Type locality: Botofogo Bay, Rio de Janeiro, Brazil (Porter 1987: 188-189); Algoa Bay, Cape Province, South Africa (Silva et al. 1996: 220).

Current placement/name: A. beauvoisii J. V. Lamouroux but status and disposition uncertain as the type was not studied in a modern context. Yendo (1905: 4) based on Madam Weber-van Bosse observations (1904: 100) of Harvey's plants (A. exilis presumed type material) proposed A. exilis as a heterotypic synonym of $A$. beauvoisii. The synonym A. beauvoisii was accepted by Prud'Homme van Reine (1994: 70) based on the concept of Price et al. (1986) for the Azorean material of $A$. exilis that had been collected and identified by Piccone (1889). In contrast to Prud'homme van Reine et al. (1994), we think the name A. exilis should be kept until more comparisons and study of type material have been conducted.

\section{Published records:}

AZORES: Agardh (1870: 363), Piccone (1889: 209) and Tittley et al. (1998: 467).

Amphiroa fragilissima (Linnaeus) J. V. Lamouroux

Basionym: Corallina fragilissima Linnaeus 1758: 806. Holotype: LINN (Yoshida 1998: 533); illustrations: 
Lamouroux (1821, Table. 21, Fig. d) and Weber-van Bosse (1904, Fig. 19, pl. XVI) as Amphiroa fragilissima (Linnaeus) J. V. Lamouroux. Type locality: Jamaica (Silva et al. 1996: 223).

Current placement/name: A. fragilissima (Linnaeus) J. V. Lamouroux according to Weber-van Bosse (1904: 90-91) based on the study of type material.

Published records:

AZORES: Amphiroa fragilissima (Linnaeus) J. V. Lamouroux. South and Tittley (1986: 42), Prud'homme van Reine (1988: 179), Neto (1994: 25) and Rosas-Alquicira and Neto (personal observation).

MADEIRA: Amphiroa fragilissima (Linnaeus) J. V. Lamouroux. Levring (1974: 69).

Amphiroa? fragilissima (Linné) J. V. Lamouroux. Neto et al. (2001: 403).

Amphiroa fragilissima. Grunow (1868: 79).

CANARY ISLANDS: Amphiroa fragilissima J. V. Lamouroux. Afonso-Carrillo et al. (1983: 30), Prud'homme van Reine et al. (1994: 70), Haroun et al. (2002: 146).

Amphiroa fragilissima (Linnaeus) J. V. Lamouroux. Afonso-Carrillo (1980b: 54), Afonso-Carrillo et al. (1984: 32), Price et al. (1986: 73), Afonso-Carrillo (1986: 190), González et al. (1986: 315), Viera-Rodríguez (1987: 242), Reyes and Sansón (1991: 74), Elejabeitia et al. (1992: 3), Pinedo et al. (1992: 32), Guadalupe et al. (1995: 37), Afonso-Carrillo and Sansón (1999: 195), Gil-Rodríguez et al. (2003: 25), Montañés et al. (2003: 124) and Sangil et al. (2003a: 87; b: 310; 2004: 89).

Amphiroa fragilissima. Jorge et al. (1984: 118) and Afonso-Carrillo and Sansón (1989: 26).

CAPE VERDE ISLANDS: Amphiroa fragilissima J. V. Lamouroux. Price et al. (1986: 73).

Amphiroa fragilissima (Linnaeus) J. V. Lamouroux. Price et al. (1986: 73) and Otero-Schmitt and Sanjuan (1992: 382).

Amphiora rigida J. V. Lamouroux

Basionym: Amphiroa rigida J. V. Lamouroux 1816: 297. Holotype: CN (Norris and Johansen 1981: 20); illustrations: Lamouroux (1816, pl. 11, Fig. 1, p. 297); Cremades et al. (1997, PC, Fig. C, p. 16). Type locality: Mediterranean (Lamouroux 1816: 297).

Current placement/name: A. rigida J. V. Lamouroux according to Norris and Johansen (1981: 21) based on study of holotype material. The presence of this species in the
Canary Islands was confirmed by Haroun et al. (2002: 139) but authors did not mentioned if they saw the material. This species is closely related to A. cryptarthrodia Zanardini, and it is likely that the reports of A. rigida in the Azores correspond to misdeterminations of A. cryptarthrodia (Rosas-Alquicira and Neto, personal observation).

Published records:

AZORES: Piccone (1889: 208), South and Tittley (1986: 42), Neto (1994: 25) and Tittley et al. (1998: 467).

Amphiroa cf. rigida J.V. Lamouroux. Tittley and Neto (1994: 7).

MADEIRA: Levring (1974: 68) and John et al. (2004: 59).

CANARY ISLANDS: Price et al. (1986: 12), Guadalupe et al. (1995: 37), Gil-Rodríguez et al. (2003: 25) and John et al. (2004: 59).

Amphiroa rigida. Afonso-Carrillo and Sansón (1989: 26).

CAPE VERDE ISLANDS: John et al. (2004: 59).

Amphiroa verruculosa Kützing

Basionym: Amphiroa verrucosa Kützing 1841: 18. Holotype: L 0055675; illustrations: Kützing (1849, pl. 79, fig. III, p. 700) and Rosas-Alquicira et al. (2010, Figs. 27-36) as Amphiroa verruculosa. Type locality: Adriatic Sea (Kützing 1849: 700).

Current placement/name: A. cryptarthrodia Zanardini according to Rosas-Alquicira et al. (2010) based on the study of neotype material. Neto et al. (2001: 412) cited a doubtful record of A. verruculosa from the Archipelago of Madeira.

Published records:

MADEIRA: Feldmann (1946: 425) and Neto et al. (2001: 412).

\section{Cheilosporum}

The genera Cheilosporum, Haliptilon and Jania were grouped into the Janieae tribe, subfamily Corallinoideae, based on the combination of the following features: (1) presence of a thick carposporophytic fusion cell; (2) gonimoblastic filaments arising from fusion cell margins; (3) male conceptacles chambers narrow with a short canal and (4) few tetrasporangia per conceptacle (Johansen and Silva 1978: 413; Table 1, p. 414). According to these authors, Cheilosporum distinguishes from other Janieae genera by possessing a marginal rather than axial location of conceptacles and the presence of pronounced intergenicular lobes. 
A complete diagnosis of the genus was provided by Johansen (1981, Appendix 1, p. 216). Womersley and Johansen (1996: 296) included a key for the Janieae genera in their book for Southern Australia where they mentioned as segregating generic characters, the branching pattern of the main axes, the intergenicular shape and the conceptacles position. Kim et al. (2007), based on combined molecular (SSU rDNA) and anatomical data (Table 1, p. 1313), determined that these characters were not useful to separate the three genera. They concluded that the Janieae should be merged only into the single genus Jania recognized by the generic characters previously listed by Johansen and Silva (1978: 413; Table 1, p. 414). This conclusion was followed by Woelkerling et al. (2008). Walker et al. (2009), based on cox1 and 18S rRNA analysis of Haliptilon squamatum and Jania rubens, also concluded they were not distinct but suggested that the clarification of the phylogenetic position of Haliptilon and Jania required more comparisons and study of original material of the genera involved. We share the opinion of Walker et al. (2009), a reason why in the present catalog the genera and species of Cheilosporum, Haliptilon and Jania are treated separately.

\section{Cheilosporum elegans J. E. Areschoug}

Basionym: Amphiroa elegans J. D. Hooker and Harvey 1849: 101. Type: TCD Colenso specimen 630; illustrations: Harvey (1849, pl. 38 lower left, p. 101). Type locality: New Zealand (Woelkerling and Nelson 2004: 54).

Current placement/name: Cheilosporum elegans J. E. Areschoug but status and disposition of species uncertain as the type was not studied in a modern context (Woelkerling and Nelson 2004: 55). This conclusion was based on specimens originally described by Hooker and Harvey (in Harvey 1849: 101) under the name Amphiroa elegans, an illegitimate name (ICBN Art. 53.1) since it is a later homonym of Amphiroa elegans Sonder (1845: 55), now considered a heterotypic synonym of Metagoniolithon stelliferum (Lamarck) Ducker (Silva et al. 1996: 260). Womersley and Johansen (1996: 315, 317) mentioned C. elegans J. E. Areschoug and also Amphiroa elegans J. D. Hooker \& Harvey in Harvey, nom. illeg. as heterotypic synonyms of Cheilosporum sagittatum (Lamouroux) J. E. Areschoug. A similar suggestion was made by Moura and Guimarães $(2002 ; 69)$ for C. elegans (J. D. Hooker \& Harvey in Harvey) Areschoug. These suggestions, however, were made without reviewing type material. Later, Kim et al. (2007) based on molecular and reproductive features proposed to merge material of Cheilosporum and Haliptilon within Jania genus and suggested the new combination Jania cultrata (Harvey) J. H. Kim, Guiry \& H.-G. Choi comb. nov. This conclusion, however, was not based on type material observations.
Published records:

CAPE VERDE ISLANDS: Cheilosporum elegans (J. D. Hooker \& Harvey) J. E. Areschoug. Askenasy (1896: 26) and Price et al. (1986: 65).

Cheilosporum elegans Harvey. Price et al. (1986: 65).

\section{Corallina}

Currently, the genus Corallina is recognized to belong to the Corallinaceae, subfamily Corallinoideae (Johansen 1981, Table 9, p. 188; Harvey et al. 2003, Table 4, p. 995). Its generic concept is consensual. The main characteristics are listed in Johansen (1981: 217), and a detailed diagnosis is provided by Womersley and Johansen (1996: 289-290). The relationship between Corallina and other Corallinoideae genera is provided by Woelkerling et al. (2008, Table 4, p. 282; Table 5, p. 287).

\section{Corallina deshayesii Montagne}

Basionym: Corallina deshayesii Montagne 1846: 130. Type: not found; illustrations: not found. Type locality: not found.

Current placement/name: C. deshayesii Montagne but status and disposition uncertain as the type was not studied in a modern context. Price et al. (1986: 73) mentioned that C. deshayesii may well be a synonym of Corallina mediterranea J. E. Areschoug. The designation/localization of the type material and its study in a modern context is required.

Published records:

SALVAGE ISLANDS: Price et al. (1986: 73).

\section{Corallina elongata J. Ellis \& Solander}

Basionym: Corallina elongata J. Ellis and Solander 1786: 119. Lectotype: Ellis's illustrations designated by Irvine and Johansen (1994: 41); illustrations: Ellis (1755, pl. 24, Fig. 3, p. 49). Type locality: Cornwall, England (Irvine and Johansen 1994: 41).

Current placement/name: C. elongata J. Ellis \& Solander according to Irvine and Johansen (1994: 41) based on the study of lectotype material. Walker et al. (2009) in their integrative taxonomic approach including phylogenetic reconstructions based on the cox1 and 18S rRNA genes in addition to a comparative morphological assessment study identified three clusters. C. officinalis sensu stricto and C. elongata from Britain corresponded to similar groups in the cox 1 tree whereas the sequences of the unidentified Corallina specimens from Madeira and Tenerife clustered with sequences of $C$. caespitosa R. H. Walker, J. Brodie \& 
L. M. Irvine and $C$. elongata from other locations. The results indicate that the name $C$. elongata has been misapplied in both the Atlantic and Mediterranean. While the concept of the species is not disputed for those samples from Britain and Ireland, the samples from Greece are C. caespitosa, and those from elsewhere in the Atlantic are of an unknown species and should be re-evaluated. Higher divergences as observed in the sequences identified to the genus from Tenerife and Madeira in the cox 1 gene can be interpreted as the result of geographical isolation and gene pool fragmentation (Hebert et al. 2003). These islands are geographically isolated in the Atlantic but it is not known if the populations interbreed with populations from elsewhere in the Atlantic and Mediterranean. For the relationship between C. elongata and C. mediterranea J. E. Areschoug, see $C$. mediterranea entry.

\section{Published records:}

AZORES: Castro and Viegas (1983: 20), South and Tittley (1986: 42), Tittley and Neto (1994: 8), Toste et al. (2003: 1270) and Wallenstein and Neto (2006: 199).

Corallina elongata Johnst. Castro and Viegas (1987: 63).

Corallina elongata. Neto (1994: 26, 2000a: 139, b: 490) and Prud'homme van Reine et al. (1994: 81) and Tittley and Neto (2000: 20).

MADEIRA: Audiffred and Prud'homme van Reine (1985: 38) and John et al. (2004: 73).

Corallina elongata. Prud'homme van Reine et al. (1994: 81).

SALVAGE ISLANDS: Price et al. (1986: 73), Prud'homme van Reine et al. (1994: 81) and John et al. (2004: 73).

CANARY ISLANDS: Price et al. (1986: 73), VieraRodríguez and Wildpret de la Torre (1986: 215), González et al. (1986: 316), Viera-Rodríguez (1987: 242), Viera-Rodríguez et al. (1987: 273), Reyes and Sansón (1991: 79), Ballesteros et al. (1992: 516), Pinedo et al. (1992: 36), Kristiansen et al. (1993: 95), Irvine and Johansen (1994: 42), Prud'homme van Reine et al. (1994: 81), Guadalupe et al. (1995: 37), Rojas-González and Afonso-Carrillo (2000: 129, 2004: 138), Gil-Rodríguez et al. (2003: 25), Haroun et al. (2003: 108), Montañés et al. (2003: 124), Sangil et al. (2003a: 94 103, b: 311, 2004: 89, 2005: 326), Afonso-Carrillo and Sobrino (2004: 149), John et al. (2004: 73), Muñoz et al. (2007: 107) and Afonso-Carrillo et al. (2009: 238).

Corallina elongata. Afonso-Carrillo (1980a: 7, b: 54), Delgado et al. (1984: 105), Haroun et al. (1984: 111), Jorge et al. (1984: 118), Afonso-Carrillo and Sansón (1989: 25), Gil-Rodríguez et al. (1992: 101), Hardisson et al. (1998: 945-950) and Tuya and Haroun (2006: 17).
Corallina granifera J. Ellis \& Solander

Basionym: Corallina granifera J. Ellis \& Solander 1786: 120. Type: whereabouts uncertain (Woelkerling and Nelson 2004: 56); illustrations: Ellis and Solander (1786, Table 21, Fig. c.C., p. 120). Type locality: Mediterranean coasts of Africa (Lamouroux 1816: 288).

Current placement/name: C. granifera J. Ellis \& Solander but status and disposition uncertain as the type was not studied in a modern context. Ardissone (1883: 465) and Yendo (1905: 30) cited C. granifera as a synonym of Corallina virgata Zanardini but no revision of type material was made. The designation/localization of the type material and its study in a modern context is required.

\section{Published records:}

AZORES: Gain (1914: 22), Lemoine (1924: 130), Schmidt (1929b: 172, 1931: 65), Feldmann (1946: 421), Weisscher (1982: 31, 1983: 63) and Audiffred and Weisscher (1984: 20).

Corallina granifera. Chapman (1955: 801) and Audiffred and Prud'homme van Reine (1985: 38).

CANARY ISLANDS: Price et al. (1986: 74) and González et al. (1986: 316).

Corallina granifera. Afonso-Carrillo (1980b: 54), Delgado et al. (1984: 105) and Price et al. (1986: 74).

Corallina granifera J. Ellis \& Solander?. Ardré (1970: 228).

Jania granifera Decaisne. Vickers (1896: 306) and Price et al. (1986: 74).

MADEIRA: Lemoine (1924: 130), Børgesen (1929: 70), Schmidt (1931: 101), Seoane-Camba (1965: 110), Weisscher (1982: 31, 1983: 63), Audiffred and Weisscher (1984: 20,33) and Audiffred and Prud'homme van Reine (1985: 38).

Corallina granifera J. Ellis \& Solander?. Ardré (1970: 228).

Jania granifera Decaisne. Gain (1914: 7) and Neto et al. (2001: 403).

SALVAGE ISLANDS: Price et al. (1986: 74).

CAPE VERDE ISLANDS: Weisscher (1982: 31) and Price et al. (1986: 74).

\section{Corallina lobata J. V. Lamouroux}

Basionym: Corallina lobata J. V. Lamouroux 1816: 286. Holotype: CN; illustrations: not found. Type locality: The Canaries (Lamouroux 1816: 286).

Current placement/name: C. lobata J. V. Lamouroux. Examination of a fragment of the type material revealed stable characters at the genus level (Garbary and Johansen 1982: 212), but the status as a distinct species within the 
genus remains uncertain until comparative studies of relevant types are undertaken. Afonso-Carrillo (unpublished information) verified that the type material of $C$. lobata was not different from the actual concept of Haliptilon virgatum (Zanardini) Garbary \& H. W. Johansen (for further comments see Price et al. 1992: 125). As C. lobata is an older name, it would have priority over $C$. virgata Zanardini (1840) (Afonso-Carrillo and Sansón 1999: 151152). For more information, see Haliptilon virgatum entry.

\section{Published records:}

MADEIRA: Afonso-Carrillo and Sansón (1999: 151).

SALVAGE ISLANDS: Afonso-Carrillo and Sansón (1999: 151).

CANARY ISLANDS: Lamouroux (1816: 286), Afonso-Carrillo et al. (1983: 46, 1984: 26, 30), Price et al. (1986: 75), Reyes and Afonso-Carrillo (1993: 127), Afonso-Carrillo and Sansón (1999: 151).

Corallina lobata. Delgado et al. (1984: 105).

CAPE VERDE ISLANDS: Afonso-Carrillo and Sansón (1999: 151).

\section{Corallina mediterranea J. E. Areschoug}

Basionym: Corallina mediterranea J. E. Areschoug 1852: 568. Type: Herb. Reg. Acad. Scientiarum Holm; illustrations: not found. Type locality: Mediterranean (Agardh 1852: 568).

Current placement/name: C. mediterranea J. E. Areschoug but status and disposition uncertain as the type was not studied in a modern context. Ardré (1970: 226) and Solms-Laubach (1881 in Ardissone 1883: 464) mentioned that the criteria used to distinguish $C$. mediterranea and Corallina officinalis Linnaeus were unsatisfactory and that further research was needed before any decision to merge both species. The historical use of $C$. mediterranea or C. officinalis at Salvagens Islands (Madeira) and in the Canary Islands is discussed in Price et al. (1986: 74).

Prud'homme van Reine et al. (1994: 81) redefined the C. mediterranea material recorded by Grunow (1868: 77) for the Archipelago of Madeira as C. elongata J. Ellis \& Solander in the Afonso-Carrillo and Sansón (1989) concept. This synonym was generalized by Price et al. (1986: 73, as C. elongata Johnst. Newton 1931: 313) and published as valid by Irvine and Johansen (1994: 41) but only based on the study of the lectotype of C. elongata.

For details on the relationship between C. mediterranea, C. elongata and C. officinalis, see C. mediterranea and C. officinalis entries.
Published records:

AZORES: Lemoine (1924: 130), Schmidt (1931: 65), Feldmann (1946: 419), Ardré et al. (1974: 178), Tittley et al. (1998: 468) and Neto (2000b: 485, 2001: 104). MADEIRA: Grunow (1868: 77), Lemoine (1924: 130), Schmidt (1931: 101) and John et al. (2004: 73).

SALVAGE ISLANDS: Price et al. (1986: 73).

CANARY ISLANDS: Lemoine (1924: 130), Børgesen (1929: 68), Schmidt (1931: 101), Feldmann (1946: 407), Seoane-Camba (1965: 110), Kohlmeyer (1967: 143), Santos Guerra et al. (1970: 24), Acuña González (1972: 5), Santos Guerra (1972: 95), Perez-Cirera (1975: 19), Afonso-Carrillo et al. (1978: 232) and Price et al. (1986: 73).

Corallina mediterranea. Vickers (1896: 295), Sauvageau (1912: 210) and González (1977b: 100).

Corallina mediterranea L. Gil-Rodríguez (1980: 138).

\section{Corallina microptera Montagne}

Basionym: Corallina microptera Montagne 1846: 130. Type: M Bourgeau; PC (Afonso-Carrillo and Sansón 1999: 152); illustrations: not found. Type locality: Orotava, Tenerife, the Canaries (Montagne 1846: 130).

Current placement/name: C. microptera Montagne. Examination of a fragment of the type material revealed stable characters at the genus level (Garbary and Johansen 1982: 212), but the status as a distinct species within genus remains uncertain until comparative studies of relevant types are undertaken. According to Bornet (1892), C. microptera from the Canary Islands is just a small form of C. elongata (as C. mediterranea J. E. Areschoug, AfonsoCarrillo and Sansón 1999: 152). Revision of the type material revealed stable characters at the genus level (Garbary and Johansen 1982: 212). The study of type specimens in a modern context is required for specific diagnosis.

Published records:

AZORES: Corallina microptera. Afonso-Carrillo and Sansón (1999: 152).

MADEIRA: Afonso-Carrillo and Sansón (1999: 152). CANARY ISLANDS: Montagne (1846: 130).

\section{Corallina millegrana Lamarck}

Basionym: Corallina millegrana Lamarck 1815: 233. Holotype: PC 0028655 General Herbarium; illustrations: not found. Type locality: Tenerife, the Canaries (Lamarck 1815: 233).

Current placement/name: C. millegrana Lamarck. Examination of a fragment of the type material revealed stable 
characters at the genus level (Garbary and Johansen 1982: 212), but the status as a distinct species within genus remains uncertain until comparative studies of relevant types are done.

Published records:

CANARY ISLANDS: Afonso-Carrillo and Sansón (1999: 152).

\section{Corallina officinalis Linnaeus}

Basionym: Corallina officinalis Linnaeus 1758: 805. Lectotype: LINN 1293. 9 (Irvine and Johansen 1994: 44); illustrations: Walker et al. (Walker et al. 2009, C. officinalis, Fig. 5a; Corallina compacta Crouan \& Crouan (PC), Fig. 5b; Corallina nana Zanardini (MCVE), Fig. 5c; Corallina calvadosii J. V. Lamouroux (PC), Figs. 5 d-e, p. 296). Type locality: European Seas (Lamouroux 1816: 284).

Current placement/name: C. officinalis Linnaeus according to Irvine and Johansen (1994: 44) and Walker et al. (2009: 295) based on the study of lectotype material. Afonso-Carrillo et al. (1983: 46) mentioned the presence of C. officinalis in the Canary Islands as doubtful. Prud'homme van Reine et al. (1994: 81) studying the material collected by Piccone and housed at PAD Herbarium redefined C. officinalis from Azores (Piccone 1889: 209), Canaries (Piccone 1884: 42) and Madeira (Piccone 1884: 42) as C. elongata J. Ellis \& Solander in the concept of Afonso-Carrillo (personal communication). However, no revision of the type material was made. Irvine and Johansen (1994: 44) provided a detailed account of $C$. officinalis in the British Isles while Womersley and Johansen (1996: 291) provided an account of the species in southern Australia.

For details on the relationship between $C$. officinalis, C. elongata and $C$. mediterranea J. E. Areschoug, see C. elongata and C. mediterranea entries.

\section{Published records:}

AZORES: Piccone (1889: 209), Gain (1914: 15, 22), Schmidt (1931: 65), Feldmann (1946: 419), Levring (1974: 69), Audiffred (1985: 174), Weisscher (1983: 64), Audiffred and Prud'homme van Reine (1985: 38), South and Tittley (1986: 42), Neto (1994: 26), Tittley and Neto (1994: 8, 2000: 20) and Tittley et al. (1998: 468).

Corallina officinalis. Schmidt (1929a: 331).

MADEIRA: Piccone (1884: 42-43), Barton (1897: 374), Gain (1914: 7), Schmidt (1931: 101), Levring (1974: 69), Weisscher (1983: 64), Audiffred and Weischer (1984: 33), Audiffred (1985: 174) and Neto et al. (2001: 403).
Corallina mediterranea Aresch = Corallina officinalis L. Audiffred and Weisscher (1984: 33).

Corallina officinalis. Augier (1985: 100).

SALVAGE ISLANDS: Price et al. (1986: 75) and John et al. (2004: 73).

CANARY ISLANDS: Price et al. (1986: 75), VieraRodríguez (1987: 242), Viera-Rodríguez et al. (1987: 273), Afonso-Carrillo and Sansón (1999: 195), GilRodríguez et al. (2003: 25) and John et al. (2004: 73). CAPE VERDE ISLANDS: Price et al. (1986: 75).

\section{Haliptilon}

The generic concept of this genus is not consensual. For the relationship between Haliptilon and other Janieae genera, see Cheilosporum entry. According to Womersley and Johansen (1996: 296), Haliptilon distinguishes from other Janieae genera by possessing a thallus pinnate with compressed axial intergenicula without lobes, usually bearing two or more subterete branchlets, sometimes adventitiously; conceptacles in terminal branchlets, usually single and with apical pores; spore-producing conceptacles with 1-3 branchlets.

\section{Haliptilon cubensis (Montagne ex Kützing)}

Garbary \& H. W. Johansen

Basionym: Jania cubensis Montagne ex Kützing, 1849: 709-710. Type: Montagne Herbarium (Agardh 1852); illustrations: Garbary and Johansen (1982, Fig. 10, p. 216) as Haliptilon cubensis (Montagne ex Kützing) Garbary \& H. W. Johansen. Type locality: Cuba (Kützing 1849: 710).

Current placement/name: H. cubensis (Montagne ex Kützing) Garbary \& H. W. Johansen. Examination of a fragment of the type material revealed stable characters at the genus level (Garbary and Johansen 1982: 212), but the status as a distinct species within genus remains uncertain until comparative studies of relevant types are done. Following their suggestion to merge material of Cheilosporum and Haliptilon within the Jania genus (Kim et al. 2007, see Cheilosporum entry), these authors suggested the new combination J. cubensis (Montagne ex Kützing 1849, p. 709-10). According to Afonso-Carrillo (unpublished results), plants from the Canary Islands reported as Corallina cubensis (Montagne ex Kützing) Kützing or H. cubensis are not morphologically different from Haliptilon virgatum (Zanardini) Garbary \& H. W. Johansen

Published records:

CANARY ISLANDS: Corallina cubensis. Delgado et al. (1984: 105) and Jorge et al. (1984: 118). 
Corallina cubensis (Montagne) Kützing. Gil-Rodríguez and Afonso-Carrillo (1980: 36), Afonso-Carrillo et al. (1983: 30, 1984: 32) and Price et al. (1992: 125). Haliptilon cubense (Montagne ex Kützing) Garbary \& H. W. Johansen. Gil-Rodríguez et al. (2003: 25) and John et al. (2004: 86).

CAPE VERDE ISLANDS: Corallina cubensis Montagne ex Kützing. Askenasy (1896: 26) and Price et al. (1992: 125).

Jania cubensis Montagne ex Kützing. Price et al. (1992: 125).

Haliptilon purpuratum (Lamarck) Garbary \& H. W. Johansen

Basionym: Corallina purpurata Lamarck 1815: 237. Type: PC; illustrations: not found. Type locality: Tenerife, the Canaries (Lamarck 1815: 237).

Current placement/name: H. purpuratum (Lamarck) Garbary \& H. W. Johansen. Examination of the thallus surface of a fragment of the type material revealed stable characters at the genus level (Garbary and Johansen 1982: 212), but the status as a distinct species within genus remains uncertain until comparative studies of relevant types are undertaken. Afonso-Carrillo and Sansón (1999: 153) mentioned that according to the original description of $C$. purpurata and the variable morphology of Haliptilon virgatum (Zanardini) Garbary \& H. W. Johansen, these two species are not distinct and a revision of both species based on examination of type material is recommended.

Published records:

CANARY ISLANDS: Haliptilon purpuratum (Lamarck) Garbary \& H. W. Johansen. Afonso-Carrillo and Sansón (1999: 153, 195).

Haliptilon squamatum (Linnaeus) Johansen,

L. Irvine \& Webster

Basionym: Corallina squamata Linnaeus 1758: 806. Lectotype: Ellis's illustrations designated by Irvine and Johansen (1994: 50); illustrations: Ellis (1755, pl. 24, Fig. c.C, p. 63). Type locality: European Seas (Lamouroux 1816: 287).

Current placement/name: Haliptilon squamatum (Linnaeus) Johansen, L. Irvine \& Webster according to Johansen et al. (1973: 212) and Irvine and Johansen (1994: 49) based on the study of lectotype material. Prud'homme van Reine et al. (1994: 81) examining the material collected by Piccone from Azores (1889), the Canaries (1884) and Madeira (Grunow 1868) housed at PAD Herbarium considered it as H. virgatum (Zanardini) Garbary \& H. W. Johansen, following the concept of Afonso-Carrillo and Sansón (1989: 25). Nevertheless, the type material was not observed. The presence of $H$. squamatum in the Archipelagos of Madeira and the Canaries is dubious and needs confirmation (Afonso-Carrillo et al. 1983: 46; Neto et al. 2001: 412). Kim et al. (2007: 1317) based on molecular and reproductive features proposed the new combination Jania squamata (Linnaeus) J. H. Kim, Guiry \& H.-G. Choi.

Published records:

AZORES: Corallina squamata J. Ellis \& Solander. Schmidt (1929b: 171, 1931: 65) and Feldmann (1946: 419).

Haliptylon squamatum. Neto (1994: 26).

Haliptilon squamatum (Linnaeus) H.W. Johansen., L.M. Irvine \& A.M. Webster. South and Tittley (1986: 42) and Tittley and Neto (1994: 9, 2005: 250).

MADEIRA: Corallina squamata. Grunow (1868: 78). Corallina squamata J. Ellis \& Solander. Grunow (1868: 78) and Schmidt (1929b: 171, 1931: 101).

Haliptilon squamatum (Linnaeus) H. W. Johansen, L.M. Irvine \& A.M. Webster. John et al. (2004: 86).

CANARY ISLANDS:1 Haliptilon squamatum (Linnaeus) H. W. Johansen, L. M. Irvine \& A. M. Webster. Afonso-Carrillo et al. (1983: 46), Price et al. (1992: 125), Irvine and Johansen (1994: 49), Irvine and Johansen (1994: 49), Afonso-Carrillo and Sansón (1999: 195), Gil-Rodríguez et al. (2003: 25) and John et al. (2004: 86).

Haliptilon virgatum (Zanardini) Garbary \& H. W. Johansen

Basionym: Corallina virgata Zanardini 1844: 1025. Type: MCVE (Stafleu and Cowan 1988: 516); illustrations: not found. Type locality: Adriatic Sea (Zanardini 1844: 1025).

Current placement/name: H. virgatum (Zanardini) Garbary \& H. W. Johansen. Examination of a fragment of the type material revealed stable characters at the genus level (Garbary and Johansen 1982: 212), but the status as a distinct species within genus remains uncertain until comparative studies of relevant types are done. Kim et al. (2007) based on molecular and reproductive features proposed to merge Haliptilon within Jania genus (see Cheilosporum entry) but did not suggest a new combination for $H$. virgatum.

For the relationship between $H$. virgatum and Corallina lobata J. V. Lamouroux, see C. lobata entry.

Published records:

AZORES: Piccone (1889: 210) and Neto and Tittley (1995: 490). 
Haliptylon virgatum (Zanardini) Garbary \& H. W. Johansen. South and Tittley (1986: 42), Prud'homme van Reine et al. (1994: 81), Tittley and Neto (1994: 9), Tittley et al. (1998: 468) and Wallenstein and Neto (2006: 199).

MADEIRA: Haliptilon virgatum (Zanardini) Garbary \& H. W. Johansen. Audiffred and Prud'homme van Reine (1985: 41) and John et al. (2004: 87).

SALVAGE ISLANDS: Price et al. (1992: 125).

CANARY ISLANDS: Piccone (1889: 210) and Price et al. (1992: 125).

Haliptilon virgata (Zanardini) Garbary \& H. W. Johansen. Viera-Rodríguez and Wildpret de la Torre (1986: 217), Price et al. (1992: 125), Prud'homme van Reine et al. (1994: 94), Afonso-Carrillo and Sansón (1999: 195), Rojas-González and Afonso-Carrillo (2002b: 100), Gil-Rodríguez et al. (2003: 25) and Muñoz et al. (2007: 107).

Haliptilon virgatum. Gil-Rodríguez et al. (1992: 112) and Prud'homme van Reine et al. (1994: 81).

Haliptilon virgata. Afonso-Carrillo and Sansón (1989: 25).

Haliptilon virgatum (Zanardini) Garbary \& H. W. Johansen. Elejabeitia et al. (1992: 8), Pinedo et al. (1992: 39), Guadalupe et al. (1995: 37), Haroun et al. (2003: 108), Montañés et al. (2003: 124), Sangil et al. (2003a: 103, b, 2004: 89, 311, 2005: 326) and John et al. (2004: 87).

\section{Jania}

The generic concept of this genus is not consensual. For the relationship between Jania and other Janieae genera, see Cheilosporum entry. According to Womersley and Johansen (1996: 296), Jania distinguishes from other Janieae genera by possessing a dichotomous thallus with terete or compressed intergenicula bearing axial conceptacles.

\section{Jania adhaerens J. V. Lamouroux}

Basionym: Jania adhaerens J. V. Lamouroux 1816: 270. Holotype: CN (Johansen 1971: 247; Cribb 1983); illustrations: not found. Type locality: Mediterranean (Lamouroux 1816: 270).

Current placement/name: J. adhaerens J. V. Lamouroux but status and disposition uncertain as the type was not studied in a modern context.

Published records:

AZORES: South and Tittley (1986: 42), Prud'homme van Reine (1988: 179), Neto (1994: 26, 2001: 104),
Tittley and Neto (1994: 9) and Tittley et al. (1998: 468).

MADEIRA: John et al. (2004: 93).

SALVAGE ISLANDS: Price et al. (1992: 135), Kristiansen et al. (1993: 95) and John et al. (2004: 93).

CANARY ISLANDS: Afonso-Carrillo (1980b: 55), Gil-Rodríguez and Afonso-Carrillo (1980: 36), Afonso-Carrillo et al. (1984: 30), González et al. (1986: 319), Afonso-Carrillo and Sansón (1989: 26, 1999: 196), Reyes and Sansón (1991: 79), Ballesteros et al. (1992: 520), Pinedo et al. (1992: 40), Price et al. (1992: 135), Ballesteros (1993: 21), Kristiansen et al. (1993: 95), Guadalupe et al. (1995: 37), Reyes et al. (2000: 140), Haroun et al. (2002: 146, 2003: 110), Rojas-González and Afonso-Carrillo (2002b: 102), Gil-Rodríguez et al. (2003: 25), Montañés et al. (2003: 124), Sangil et al. (2003a: 103, b: 311), John et al. (2004: 93), Sangil et al. (2004: 89, 2005: 326) and Muñoz et al. (2007: 107).

CAPE VERDE ISLANDS: Otero-Schmitt and Sanjuan (1992: 382), Price et al. (1992: 135) and Otero-Schmitt (1993: 47).

\section{Jania capillacea Harvey}

Basionym: Jania capillacea Harvey 1853: 84-85. Holotype: TCD (Toumey 70; Dawson 1953: 116; Cribb 1983); illustrations: not found. Type locality: Honda Bay, Florida, USA (Silva et al. 1996: 241).

Current placement/name: J. capillacea Harvey but status and disposition uncertain as the type was not studied in a modern context. Similarities between this species and J. adhaerens J. V. Lamouroux are discussed in Cribb (1983) and Schneider and Searles (1991). Further comments on the relation between $J$. capillacea and Jania pumila J. V. Lamouroux for the Canary Islands in J. pumila entry.

\section{Published records:}

AZORES: Neto (2001: 104) and Wellenstein and Neto (2006: 1999).

MADEIRA: John et al. (2004: 93).

SALVAGE ISLANDS: Price et al. (1992: 135) and John et al. (2004: 93).

CANARY ISLANDS: Afonso-Carrillo and Sansón (1989: 26, 1999: 196), Reyes and Sansón (1991: 79), Pinedo et al. (1992: 40), Price et al. (1992: 135), Ballesteros (1993: 22), Prud'homme van Reine et al. (1994: 94), Gil-Rodríguez et al. (2003: 25), Haroun et al. (2003: 110), Sangil et al. (2003a: 103, b: 311) and John et al. (2004: 93).

Jania capillacea J. V. Lamouroux. Afonso-Carrillo et al. (1983: 46, 1984: 30) and Price et al. (1992: 135). 
CAPE VERDE ISLANDS: Otero-Schmitt and Sanjuan (1992: 382), Price et al. (1992: 135) and Otero-Schmitt (1993: 51).

Jania crassa J. V. Lamouroux

Basionym: Jania crassa J. V. Lamouroux 1821: 23. Holotype: CN Lamouroux Herbarium under Jania in folder c8f74 (Woelkerling and Nelson 2004: 53); illustrations: Lamouroux (1821, pl. 69, Figs. 9-10, p. 23) and Johansen (1971, Fig. 10, p. 244) as J. crassa; Johansen and Womersley (1994, Fig. 37, p. 622) as Jania verrucosa J. V. Lamouroux; see comments. Type locality: Dusky Sound, South Island, New Zealand (Lamouroux 1821: 23).

Current placement/name: J. verrucosa J. V. Lamouroux but status and disposition uncertain as the type of J. verrucosa was not studied in a modern context. Johansen and Womersley (1994: 617) and Womersley and Johansen (1996: 305, 307) considered $J$. crassa as a heterotypic synonym of $J$. verrucosa stating that they are almost "certainly conspecific at least in southern Australia". This conclusion was only based on the study of the holotype of $J$. crassa. However, according to Woelkerling and Nelson (2004: 65), the proposed conspecifity needs to be confirmed through a comparative study of both types.

Published records:

AZORES: South and Tittley (1986: 43), Neto (1994: 26) and Tittley and Neto (1994: 9).

Jania crassa. Prud'homme van Reine (1988: 179), Stengenga et al. (1997: 585) and Neto (2000a: 140, b: 490).

CAPE VERDE ISLANDS: Otero-Schmitt and Sanjuan (1992: 384) and Price et al. (1992: 136).

Jania intermedia (Kützing) P. C. Silva

Basionym: Corallina intermedia Kützing 1858: 37-38, 42. Type: not found: illustrations: Kützing (1858, pl. 79, Fig. I, p. 36-38; pl. 86, Fig. IV, p. 42). Type locality: Cape of Good Hope, South Africa (Silva et al. 1996: 242).

Current placement/name: J. intermedia (Kützing) P. C. Silva but status and disposition uncertain as the type was not studied in a modern context. Silva et al. (1996: 242) mentioned that the correct combination is $J$. intermedia and not Jania intermedia Kützing which was only a bibliographic reference and not the name of the basionym. Neto et al. (2001: 412.) studying Madeira specimens cited it as doubtful record mentioning that "it might be a variety of $J$. rubens (Linnaeus) J.V. Lamouroux". According to Woelkerling and Nelson (2004: 57), this name should be considered a nomen nudum as there are no valid diagnosis descriptions.
Published records:

MADEIRA: Corallina intermedia Grunow. Neto et al. (2001: 412).

Jania longifurca Zanardini

Basionym: Jania longifurca Zanardini 1844: 1025. Type: probably in MCVE Zanardini's collections; illustrations: not found. Type locality: Dalmatia, Italy (Zanardini 1844: 1025).

Current placement/name: J. longifurca Zanardini but status and disposition uncertain as the type was not studied in a modern context. Sansón et al. (1991: 531) mentioned that this species is poorly known in the Canary Islands and needs further studies. The designation/localization of the type material and its study in a modern context is required.

Published records:

AZORES: Feldmann (1946: 421), South and Tittley (1986: 43), Neto (1994: 26), Tittley et al. (1998: 468) and Neto (2000a: 140, b: 490, 2001: 105).

MADEIRA: Levring (1974: 70), Sansón et al. (1991: 530) and Neto et al. (2001: 404).

CANARY ISLANDS: Sansón et al. (1991: 530), Afonso-Carrillo and Sansón (1999: 196), Haroun et al. (2002: 146) and Gil-Rodríguez et al. (2003: 25).

Jania micrarthrodia J. V. Lamouroux

Basionym: Jania micrarthrodia J. V. Lamouroux 1816: 271. Holotype: CN Lamouroux Herbarium; illustrations: Lamouroux (1816, pl. 9, Fig. 5a; pl. 69, Figs. 7-8, p. 271); Johansen and Womersley (1994, Figs. 32-36, p. 622). Type locality: Australasia (Lamouroux 1816: 271).

Current placement/name: J. micrarthrodia J. V. Lamouroux according to Johansen and Womersley (1994: 611613) based on the study of type material. Gil-Rodríguez et al. (2003: 212) mentioned that the material of J. micrarthrodia for the Canaries could not be located.

\section{Published records:}

CANARY ISLANDS: Price et al. (1992: 136) and Afonso-Carrillo and Sansón (1999: 196).

\section{Jania natalensis Harvey}

Basionym: Jania natalensis Harvey 1849: 107. Type: TCD (Johansen 1971: 247); illustrations: not found. Type locality: Port Natal, South Africa (Johansen 1971: 247).

Current placement/name: Jania verrucosa J. V. Lamouroux but status and disposition uncertain as the type was not studied in a modern context. Johansen and Womersley 
(1994: 616) merged $J$. natalensis in synonymy with $J$. verrucosa but no revision of the type material was made. Agardh (1870: 363) cited J. natalensis as doubtful to the Azores (Santa Maria).

\section{Published records:}

AZORES: Schmidt (1929b: 172, 1931: 66). Corallina natalensis Kützing. Neto (2000b: 485). Jania natalensis?. Agardh (1870: 363) and Piccone (1889: 214).

Jania? Natalensis Harvey. Gain (1914: 22).

Jania pumila J. V. Lamouroux

Basionym: Jania pumila J. V. Lamouroux 1816: 269. Holotype: CN Lamouroux Herbarium; illustrations: Lamouroux (1816, pl. 9, Fig. 2, p. 269). Type locality: Red Sea and Western Indies (Lamouroux 1816: 269).

Current placement/name: J. pumila J. V. Lamouroux but status and disposition uncertain as the type was not studied in a modern context. The holotype specimen of $J$. pumila housed in Lamouroux's Herbarium in Caen is in depauperate and/or sterile conditions being difficult to interpret (Johansen and Womersley 1994: 610; Abbott 1999: 189). Villena-Balsa et al. (1987: 20) revising material from the Canary Islands identified it provisionally as $J$. pumila. They mentioned that the material could belong to other species also characterized by reduced-size plants and not correctly described e.g. Jania gibbosa J. V. Lamouroux, J. pygmea J. V. Lamouroux, J. compressa J. V. Lamouroux and J. capillacea Harvey.

Published records:

MADEIRA: Levring (1974: 70), González (1978: 48) and Neto et al. (2001: 404).

SALVAGE ISLANDS: Price et al. (1992: 136) and John et al. (2004: 93).

CANARY ISLANDS: Price et al. (1992: 136), AfonsoCarrillo et al. (1978: 232, 1983: 30, 1984: 30), González (1978: 48), Gil-Rodríguez and Afonso-Carrillo (1980: 36), Pinedo et al. (1992: 40), Afonso-Carrillo and Sansón (1999: 196), Haroun et al. (2003: 112), GilRodríguez et al. (2003: 25), Sangil et al. (2003a: 103, 2005: 326) and John et al. (2004: 93).

Jania pumila. Afonso-Carrillo and Sansón (1989: 25) and Price et al. (1992: 136).

Jania rubens (Linnaeus) J. V. Lamoroux var. corniculata (Linnaeus) Yendo

Basionym: Corallina corniculata Linnaeus 1758: 806. Lectotype: LINN 1293.19 (Irvine and Johansen 1994: 56); illustrations: not found. Type locality: European Ocean (Irvine and Johansen 1994: 56).

Current placement/name: Jania rubens (Linnaeus) J. V. Lamoroux var. corniculata (Linnaeus) Yendo but status and disposition uncertain as the type was not studied in a modern context. Irvine and Johansen (1994: 56) in their revision of the British Isles material considered the name $J$. rubens var. corniculata (Linnaeus) Yendo as valid but without checking the type material. Recently, John et al. (2004: 93) considered J. corniculata (Linnaeus) J. V. Lamouroux as a synonym of Jania rubens (Linnaeus) J. V. Lamouroux but did not provide any taxonomic comments. In their integrative taxonomic approach including phylogeny reconstructions based on the cox 1 and 18S rRNA genes in addition to a comparative morphological assessment study Walker et al. (2009) observed that J. rubens var. rubens and J. rubens var. corniculata clustered together in both phylogenies suggesting that for those genes there was no genetic basis for the morphological variation. These conclusions however were not based on type material observations.

Published records:

AZORES: Gain (1914: 22), Tittley et al. (1998: 468) and Neto (2000b: 485, 2001: 105).

Jania corniculata J. V. Lamouroux. Piccone (1889: 213). Jania corniculata (Linnaeus) J. V. Lamouroux. South and Tittley (1986: 42).

Jania cf. corniculata (Linnaeus) J.V. Lamouroux. Neto (1994: 26) and Tittley and Neto (1994: 9).

Jania rubens J. V. Lamouroux var. corniculata (Linnaeus) Yendo. Schmidt (1931: 66).

MADEIRA: Jania cf. corniculata. Neto et al. (2001: 404). Jania corniculata (Linnaeus) J. V. Lamouroux. Audiffred and Prud'homme van Reine (1985: 43).

SALVAGE ISLANDS: Jania cf. corniculata. John et al. (2004: 93).

CANARY ISLANDS: Jania corniculata (Linnaeus) J. V. Lamouroux. Gil-Rodríguez and Afonso-Carrillo (1980: 36), Afonso-Carrillo et al. (1983: 30, 1984: 30) and Price et al. (1992: 135).

Jania corniculata. Afonso-Carrillo and Sansón (1989: 26). Jania rubens (Linnaeus) J. V. Lamouroux var. corniculata (Linnaeus) Yendo. Price et al. (1992: 135) and Irvine and Johansen (1994: 57).

Jania rubens (Linnaeus) J. V. Lamoroux var. rubens

Basionym: Corallina rubens Linnaeus 1758: 806. Lectotype: UPS Herb. Burser vol. XX, 72; designated by Irvine and Johansen (1994: 56); illustrations: Lamoroux (1816, pl. 
9, figs 6-7, p. 272) as Jania rubens (Linnaeus) J. V. Lamouroux. Type locality: European Ocean (Linnaeus 1758: 806).

Current placement/name: J. rubens (Linnaeus) J. V. Lamoroux var. rubens, a conclusion of Irvine and Johansen (1994: 56) after studying the lectotype in a modern context. Price et al. (1992: 136) suggested that J. rubens and Corallina rubens J. Ellis \& Solander in González (1977a: 26) are synonyms. Prud'homme van Reine et al. (1994: 94) confirmed the diagnosis of the $J$. rubens material from Cape Verde Islands collected by Piccone (1886) and housed at PAD and $\mathrm{W}$ Herbarium but recognized that material was from Tenerife (the Canaries) and not from Cape Verde Islands. They followed Taylor's (1960) concept and did not review the type material.

\section{Published records:}

AZORES: Gain (1914: 15, 22) and Prud'homme van Reine et al. (1994: 94).

Jania rubens. Schmidt (1929a: 331).

Jania rubens (Linnaeus) J. V. Lamouroux. Feldmann (1946: 417), Castro and Viegas (1983: 20, 1987: 63), Weisscher (1983: 70), South and Tittley (1986: 43), Tittley and Neto (1994: 9), Neto (2000a: 140, 2000b: 490-491), Toste et al. (2003: 1270) and Wallenstein and Neto (2006: 199).

Jania rubens J. V. Lamouroux. Schmidt (1931: 66).

Jania rubens. Agardh (1870: 363), Palminha (1957:

66), Neto (1994: 26, 2000b: 490) and Neto and Tittley (1995: 489).

Jania rubens (Linnaeus) Areschoug. Lemoine (1924: 130).

Jania rubens (Linnaeus) J. V. Lamouroux var. rubens. Audiffred and Prud'homme van Reine (1985: 43) and Irvine and Johansen (1994: 55).

MADEIRA: Corallina rubens J. V. Lamouroux. Gain (1914: 10) and John et al. (2004: 93).

Jania rubens J. V. Lamouroux. Piccone (1884: 10), Gain (1914: 9) and Schmidt (1931: 101).

Jania rubens (Linnaeus) J. V. Lamouroux. Grunow (1868: 78) and Levring (1974: 70).

Jania rubens. Johnston (1969: 215), Augier (1985: 100) and Afonso-Carrillo and Sansón (1989: 26).

Jania rubens (Linnaeus) J. E. Areschoug. Lemoine (1924: 130).

SALVAGE ISLANDS: Price et al. (1992: 136) and John et al. (2004: 93).

CANARY ISLANDS: Corallina (Jania) rubens Linnaeus. Askenasy (1896: 26) and Prud'homme van Reine et al. (1994: 94).
Jania rubens. Johnston (1969: 215), González (1977b: 100), Delgado et al. (1984: 106), Gil-Rodríguez et al. (1992: 109) and Price et al. (1992: 136).

Jania rubens (Linnaeus) J. V. Lamouroux. Ardré (1970: 229), Santos Guerra et al. (1970: 24), CordeiroMarino (1978: 50), González (1978: 48), AfonsoCarrillo et al. (1978: 232, 1984: 30), Afonso-Carrillo and Gil-Rodríguez (1980: 165), Gil-Rodríguez and Afonso-Carrillo (1980: 36), López Hernández and Gil-Rodríguez (1981: 156), Weisscher (1983: 70), González et al. (1986: 319), Viera-Rodríguez and Wildpret de la Torre (1986: 216), Reyes and Sansón (1991: 79), Pinedo et al. (1992: 40), Medina and Haroun (1993: 110), Kristiansen et al. (1993: 95), Guadalupe et al. (1995: 37), Afonso-Carrillo and Sansón (1999: 196), Gil-Rodríguez et al. (2003: 25), Rojas-González and Afonso-Carrillo (2002a: 33), Haroun et al. (2003: 112), Montañés et al. (2003: 124), Sangil et al. (2003a: 103), John et al. (2004: 93), RojasGonzález and Afonso-Carrillo (2004: 138) and Muñoz et al. (2007: 107).

Jania rubens J. V. Lamouroux. Vickers (1896: 306), Schmidt (1931: 101 and Price et al. (1992: 136).

Jania rubens (Linnaeus). Piccone (1884: 42, 56) and Acuña González (1972: 5).

Jania rubens. Price et al. (1992: 136).

Jania rubens (Linnaeus) J. V. Lamouroux var. rubens. Irvine and Johansen (1994: 55).

CAPE VERDE ISLANDS: Corallina (Jania) rubens Linneaus. Price et al. (1992: 136).

Jania rubens (Linnaeus) J. V. Lamouroux. Piccone (1886: 66), Price et al. (1992: 136) and Prud'homme van Reine et al. (1994: 94).

Jania rubens J. V. Lamouroux. Schmidt (1931: 101). Jania cf. rubens (Linnaeus) J. V. Lamouroux. OteroSchmitt and Sanjuan (1992: 382).

Jania tenella (Kützing) Grunow

Basionym: Corallina tenella Kützing 1858: 41. Holotype: L (Dawson 1953: 121); illustrations: Kützing (1858, pl. 85, fig. II, p. 41). Type locality: Naples, Italy (Silva et al. 1996: 244).

Current placement/name: J. tenella (Kützing) Grunow but status and disposition uncertain as the type was not studied in a modern context.

Published records:

CAPE VERDE ISLANDS: Corallina (Jania) tenella Kützing. Price et al. (1992: 136). 


\section{Jania verrucosa J. V. Lamouroux}

Basionym: Jania verrucosa J. V. Lamouroux 1816: 270. Holotype: CN Lamouroux Herbarium (Womersley and Johansen 1996: 305); illustrations: Lamouroux (1816, pl. 9, Fig. 4 a.B, p. 270). Type locality: North America (Lamouroux 1816: 270).

Current placement/name: J. verrucosa J. V. Lamouroux but status and disposition uncertain as the type was not studied in a modern context. For the relationship between $J$. verrucosa, J. natalensis and J. cryptarthrodia, see J. natalensis and J. cryptarthrodia entries.

\section{Published records:}

AZORES: Jania verrucosa. Neto (2000b: 491, 2001:105).

CAPE VERDE ISLANDS: Price et al. (1992: 136).

\section{Discussion}

From the 31 names of species and infraspecific taxa of geniculate Corallinales recorded from the Macaronesian region, four are based on type material collected from localities within this region, while the rest $(87 \%)$ are based on types from localities elsewhere (Table 1). All species are validly published (ICBN, Art. 6.2, 29.1, 42.3 and 60). The correct application of these names to species and specific taxa, however, is linked to an understanding of the type material and to the provisions of the ICBN (McNeill et al. 2006).

For Haliptilon cubensis, $H$. virgatum and the four names based on Macaronesian collections (Corallina lobata, $C$. microptera, C. millegrana and Haliptilon purpurata), only a fragment of the holotype material was studied. The generic placement of the taxa was confirmed by ultrastructural investigations but the status of the species could not be determined (Garbary and Johansen 1982). As a result, published information does not include detailed specific morphological and anatomical accounts, and its nomenclature lacks the foundations essential for stability. Therefore, although those taxa are currently treated as distinct species by various authors, this treatment requires substantiation through morphological, anatomical and ultrastructural detailed studies of relevant type material.

From the list compiled in the present work, 15 taxa have not been studied in a modern context. Jania intermedia is a nomen nudum (ICBN, Art. 1) and therefore nomenclaturally illegitimate. The remaining 14 taxa, although listed as distinct species in various publications, require re-assessment through further studies of relevant type material. The same situation happens with the proposed heterotypic synonyms. An example is the synonymy of Corallina mediterranea with $C$. elongata published by Irvine and Johansen (1994: 41). The segregating characters defined by these authors for $C$. elongata, related to reproductive and vegetative morphology, cannot be contrasted with the available original description of $C$. mediterranea from Areschoug (1852: 568-569). Also, the presence in the main axes of intergenicula as long as wide, described by Walker et al. (2009: 295-296) as distinguishing feature for C. elongata, does not agree with the description of $C$. mediterranea. The occurrence of most of these taxa in Macaronesia has yet to be verified as most records represent occasional findings from one single location.

Only ten types of Corallinales occurring in Macaronesia have been studied in a modern context. From these, two (Jania crassa and Amphiroa verruculosa) are considered heterotypic synonyms of other taxa. The heterotypic synonymy of Jania crassa with Jania verrucosa (Johansen and Womersley 1994), however, requires further studies comparing both types. The remaining eight species are considered to be distinct taxa. Their diagnosing characters were emended based on, respectively, vegetative and reproductive anatomy in the case of Amphiroa (Norris and Johansen 1981: 5-6), vegetative and reproductive morphology in Corallina (Walker et al. 2009: 295; Table 4, p. 296) and morphological and anatomical vegetative characters in Jania (Johansen and Womersley 1994: 606). The confirmation of these species in the Macaronesia requires the study of their voucher specimens in light of these new concepts.

To summarize, only 8 of the 31 species and infraspecific taxa of geniculate Corallinales listed for Macaronesia have been confirmed to represent distinct species. Three others have been found to be heterotypic synonyms of other taxa and one (Jania intermedia) is nomenclaturally illegitimate. There remains 19 taxa that have yet to be fully reassessed through detailed studies encompassing specific morphological, anatomical and ultrastructural investigations, preferably complemented with molecular studies. This task has many difficulties, starting with the fact that for three species (Corallina deshayesii, C. granifera and C. intermedia) the type collection whereabouts are uncertain. However, this kind of taxonomic work may confirm the molecular conclusions of Kim et al. (2007) suggesting that the genera Cheilosporum, Haliptilon and Jania (tribe Janieae) should be merged into a single genus Jania recognized by the generic characters listed by Johansen and Silva (1978: 413, Table 1, p. 414)

\section{Conclusion}

The present catalog and its analysis represent initial steps in creating a reliable database on the species diversity of 
geniculate Corallinales in the Macaronesian region. Although 31 names of geniculate Corallinales have been recorded for this region, the actual number of species and genera present is uncertain and will continue to remain so until detailed monographic studies are undertaken. How many of the names previously used for the Macaronesian region taxa can correctly be applied to specimens for this region also remains uncertain as does the number of species present, but so far undetected. An accurate figure of the actual diversity for the Macaronesian geniculate corallines requires extensive work involving new collections, the detailed study of fresh material, historical collections and type material, complemented, if possible, with molecular evaluations.

Acknowledgments We thank Drs. Willem F. Prud'homme van Reine (National Herbarium Nederland-L) and Bruno de Reviers (Muséum National d'Histoire Naturelle-PC) who provided specialized old literature and/or type material information, Ian Tittley (Natural History Museum), José M. N. Azevedo and Gustavo Martins for the English revision of the manuscript, Nuno Álvaro for the study area map, and to Dr. Inka Bartsch and an anonymous reviewer for their useful comments and suggestions. This work was partly supported by the Programme AlBan, the European Union Programme of High Level Scholarships for Latin America (through scholarship E05D060221MX) and "Consejo Nacional de Ciencia y Tecnología" doctoral scholarship 176162, the UNAMUNO Programme of $\mathrm{PhD}$ Scholarships for Europe, and "Centro de Investigação de Recursos Naturais", University of the Azores.

\section{References}

Abbott IA (1999) Marine red algae of the Hawaiian Islands. Bishop Museum Press, Honolulu

Acuña González A (1972) Observaciones ecológicas sobre las algas de la zona litoral de Las Galletas Tenerife. Vieraea 1:2-5

Afonso-Carrillo J (1980a) Algunas observaciones sobre la distribución vertical de las algas en la isla del Hierro (Canarias). Vieraea 10:3-16

Afonso-Carrillo J (1980b) Nota sobre algunas Corallinaceae (Rhodophyta) nuevas para la flora ficólogica de las Islas Canarias. Vieraea 10:53-58

Afonso-Carrillo J (1986) Observaciones en Amphiroa fragilissima (L.) Lamouroux (Corallinaceae Rhodophyta) con el microscopio electrónico de barrido. Vieraea 16:189-192

Afonso-Carrillo J (1988) Structure and reproduction of Spongites wildpretii sp. nov. (Corallinaceae, Rhodophyta) from the Canary Islands, with observations and comments on Spongites absimile comb. nov. Br Phycol J 23:89-102

Afonso-Carrillo J, Gil-Rodríguez MC (1980) Datos para la flora marina de la isla de Fuerteaventura. Vieraea 10:147-170

Afonso-Carrillo J, Sansón M (1989) Clave ilustrada para la determinación de los macrófitos marinos bentónicos de las Islas Canarias. Departamento de Biología Vegetal (Botánica), Universidad de La Laguna, La Laguna

Afonso-Carrillo J, Sansón M (1999) Algas hongos y fanerógamas marinas de las Islas Canarias. Clave analítica. Materiales Didácticos Universitarios. Serie Biología/2. Universidad de La Laguna, La Laguna

Afonso-Carrillo J, Sobrino C (2004) Two amphi-Atlantic species of Botryocladia (Rhodymeniales Rhodophyta) in the Canary Islands (Eastern Atlantic). Cryptogamie Algol 25:147-159
Afonso-Carrillo J, Gil-Rodríguez MC, Wildpret de la Torre W (1978) Estudio de la vegetación algal de la costa del futuro polígono industrial de Granadilla (Tenerife). Vieraea 8:201-242

Afonso-Carrillo J, Gil-Rodríguez MC, Haroun-Tabraue R, VillenaBalsa M, Wildpret de la Torre W (1983) Adiciones y correcciones al catálogo de algas marinas bentónicas para el Archipiélago Canario. Vieraea 13:27-49

Afonso-Carrillo J, Gil-Rodríguez MC, Wildpret de la Torre W (1984) Algunas consideraciones florísticas corológicas y ecológicas sobre las algas Corallinaceae (Rhodophyta) de las islas Canarias. Anales Biol 2:23-37

Afonso-Carrillo J, Sangil C, Sansón M (2009) Lomentaria benahoarensis (Lomentariaceae, Rhodophyta), a diminutive epiphytic new species from La Palma, Canary Islands (eastern Atlantic Ocean). Bot Mar 52:236-247

Agardh JG (1852) Species genera et ordines algarum, seu descriptiones succinctae specierum, generum et ordinum, quibus algarum regnum constituitur. Volumen secundum: algas florideas complectens. Part 3, fasc. 1. C.W.K. Gleerup, Lundae [Lund]

Agardh JG (1870) Om de under Korvetten Josephines expedition sistliden sommar insamlade Algerne. Ofver K Vet Ak Förhandl 27:359-366

Ardissone F (1883) Phycologia mediterranea. Parte Prima Floridee. Mem Soc Cittog Ital 1:1-516

Ardré F (1970) Contribution à l'etude des algues marines du Portugal I-La Flore. Port Acta Biol, ser B10:137-555

Ardré F, Boudouresque CF, Cabioch J (1974) Symphyocladia marchantioides (Harv.) Falkenberg (Rhodomélacées Ceramiales) aux Açores. Bull Soc phycol Fr 19:178-182

Areschoug JE (1852) Ordo XII. Corallineae. In: Agardh JG (ed) Species genera et ordines algarum. Volumen secundum: algas florideas complectens. Lund, Sweden, pp 506-576

Askenasy ME (1896) Énumeration des algues des iles du Cap Vert. Bol Soc Broteriana 13:1-26

Audiffred PAJ (1985) Marine algae of El Hierro (Canary Islands). Vieraea 14:157-183

Audiffred PAJ, Prud'homme van Reine WF (1985) Marine algae of Ilha do Porto Santo and Deserta Grande (Madeira Archipelago) (Cancap Project Contributions No. 40). Bolm Mus munic Funchal 37:20-51

Audiffred PAJ, Weisscher FLM (1984) Marine algae of Salvagem Grande (Salvage Island Macaronesia) (Cancap Project Contribution No. 37). Bolm Mus munic Funchal 36:5-37

Augier H (1985) Première contribution a la cartographie des biocenoses marines benthiques de l'ile de Madere. Bolm Mus munic Funchal 37:86-129

Bailey JC (1999) Phylogenetic positions of Lithophyllum incrustans and Titanoderma pustulatum (Corallinaceae, Rhodophyta) based on 18S rRNA gene sequence analyses, with a revised classification of the Lithophylloideae. Phycologia 38:208-216

Ballesteros E (1993) Algunas observaciones sobre las comunidades de algas profundas en Lanzarote y Fuerteventura (Islas Canarias). Vieraea 22:17-27

Ballesteros E, Sansón M, Reyes J, Afonso-Carrillo J, Gil-Rodríguez MC (1992) New records of benthic marine algae from the Canary Islands. Bot Mar 35:513-522

Barton ES (1897) Welwitsch's African marine algae. J Bot, Lond 35:369-374

Børgesen F (1929) Marine algae from the Canary Islands especially from Teneriffe and Gran Canaria II. Rhodophyceae. Part II. Cryptonemiales, Gigartinales and Rhodynemiales. Biol Meddr K danske Vidensk Skr 8:1-97

Bornet E (1892) Les algues de P.-K.-A. Schousboe recoltées au Maroc et dans la Méditerranée de 1815 a 1829. Mém Soc natn Math Cherbourg 28:165-376

Castro ML, Viegas MC (1983) Estudo dos povoamentos de algas fotófilas da Ilha de S. Miguel (Açores). 1. Resultados preliminares 
sobre a facies de Corallina elongata Ellis and Solander. Arquipélago 4:7-30

Castro ML, Viegas MC (1987) Contribuçao para o estudo da zona intertidal (substarto rochoso) da ilha de San Miguel-Acores. Fácies de Corallina elongata Ellis and Solander. Resultados preliminares. Cuad Marisq Publ 11:59-69

Chapman G (1955) Aspects of the fauna and flora of the Azores. VI. Density of animal life in the coralline alga zone. Ann Mag Nat Hist 12:801-805

Cordeiro-Marino M (1978) Rodofíceas bentônicas marinhas do Estado de Santa Catarina. Rickia 7:1-243

Cremades J, Bárbara I, Veiga JA (1997) Amphiroa van-bosseae (Corallinales Rhodophyta) on European Atlantic coasts. Cryptogamie Algol 18:11-17

Cribb AB (1983) Marine algae of the southern Great Barrier Reef Part. 1. Rhodophyta. Australian coral reef Society, Brisbane

Dawson EY (1953) Marine red algae of Pacific Mexico. Part 1. Bangiales to Corallinaceae subf. Corallinoidae. Allan Hancock Pacif Exped 17:1-239

Delgado E, González MN, Jorge D (1984) Contribución al estudio de la vegetación ficológica de la zona de Arinaga (Gran Canaria). Botanica Macaron 12-13:97-110

Elejabeitia Y, Reyes J, Afonso-Carrillo J (1992) Algas marinas bentónicas de Punta del Hidalgo, Tenerife (Islas Canarias). Vieraea 21:1-28

Ellis J (1755) An essay towards a natural history of the corallines and other marine productions of the like kind commonly found on the coasts of Great Britain and Ireland. To which is added the description of a large marine polype taken near the North Pole by the Whale-fishers in the summer 1753. Privately Published, London

Ellis J, Solander D (1786) The natural history of many curious and uncommon zoophytes collected from various parts of the globe by the late John Ellis. Systematically arranged and described by the late Daniel Solander. B. White and Son, London

Feldmann J (1946) La flore marine des iles Atlantides. Mém Soc Biogéogr 8:395-435

Gain L (1914) Algues provenant des campagnes de "l Hirondelle" II" (1911-1912). Bull Inst Océanogr Monaco 279:1-23

Garbary DJ, Johansen HM (1982) Scanning electron microscopy of Corallina and Haliptilon (Corallinaceae Rhodophyta): surfaces features and their taxonomic implications. J Phycol 18:211-219

Gil-Rodríguez MC (1980) Revisión taxonómica-ecológica del género Cystoseira C. Ag. en el Archipiélago Canario. Vieraea 9:115-148

Gil-Rodríguez MC, Afonso-Carrillo J (1980) Catálogo de las algas marinas bentónicas (Cyanophyta, Chlorophyta, Phaeophyta y Rhodophyta) para el Archipiélago Canario (Tenerife). Aula de Cultura, Excmo. Cabildo Insular, Santa Cruz de Tenerife

Gil-Rodríguez MC, Afonso-Carrillo J, Wildpret de la Torre W (1987) Praderas marinas de Zostera noltii (Zosteraceae) en las Islas Canarias. Vieraea 17:43-416

Gil-Rodríguez MC, Afonso-Carrillo J, Haroun RJ (1992) Flora ficológica de las islas Canarias. In: Kunkel G (ed) Flora y vegetación del Archipiélago Canario. Tratado Florístico $1^{a}$ Parte. EDIRCA, Las Palmas de Gran Canaria, pp 95-121

Gil-Rodríguez MC, Haroun RJ, Ojeda RA, Berecibar ZE, Domínguez SP, Herrera MB (2003) Protoctista. In: Moro L, Martín JL, Garrido MJ, Izquierdo I (eds) Lista de especies marinas de Canarias (algas, hongos, plantas y animales). Consejería de Política Territorial y Medio Ambiente del Gobierno de Canarias, pp 17-33

González N (1977a) Estudio de la vegetación litoral de la zona de Maspalomas. Botanica Macaron 4:23-30

González N (1977b) Estudio de la vegetación bentonica litoral del nordeste de la isla de Gran Canaria (Bañaderos, San Felipe, Sardina, Las Nieves). Botanica Macaron 4:85-104

González N (1978) Estudio algológico de la Playa del Burrero (Gran Canaria). Botanica Macaron 6:43-51
González N, Rodrigo PJD, Suárez RC (1986) Flora y vegetación del Archipielago Canario. Las Palmas de Gran Canaria, MAE/Spain

Grunow A (1868) Algen. In: Fenzl E (ed) Reise der Österreichischen Fregatte Novara um die Erde in den Jahren 18571858 und 1859 unter den Befehlen des Commodore B. von Wüllerstorf-Urbair. Botanischer Theil 1. Sporenpflanzen. Kaiserl. -Königl. Hof- und Staatsdruckerei, Wien, pp 1-104

Guadalupe ME, Gil-Rodríguez MC, Hernández-González MC (1995) Fitobentos de Arrecife de Lanzarote, Reserva de la Biosfera (Islas Canarias). Cryptogamie Algol 16:33-46

Hamel G, Lemoine P (1953) Corallinacées de France et d'Afrique du Nord. Archs Mus Hist nat Paris 7.1:15-136

Hardisson A, Frias I, De Bonis A (1998) Mercury in algae of the Canary Islands littoral. Enviro Inter 24:945-950

Haroun RJ, Gil-Rodríguez MC, Afonso-Carrillo J, Wildpret de la Torre W (1984) Vegetación bentónica del Roque de Los Órganos (Gomera). Anales Biol 2:107-117

Haroun RJ, Gil-Rodríguez MC, Díaz de Castro J, Prud'homme van Reine WF (2002) A checklist of the marine plants from the Canary Islands (central eastern Atlantic Ocean). Bot Mar 45:139169

Haroun RJ, Gil-Rodríguez MC, Wildpret de la Torre W (2003) Plantas marinas de las Islas Canarias. Canseco editores, Talavera de la Reina

Harvey WH (1849) Nereis australis or algae of the southern ocean: being figures and descriptions of marine plants collected on the shores of the Cape of Good Hope the extra-tropical Australian colonies Tasmania New Zealand and the Antarctic regions; deposited in the Herbarium of the Dublin University. Part 2. Reeve Brothers, London

Harvey WH (1853) Nereis boreali-americana; or, contributions towards a history of the marine algae of the atlantic and pacific coasts of North America. Part II. Rhodospermeae. Smithson Contr Knowl 5:[i-ii], [1]-258

Harvey AS, Broadwater ST, Woelkerling WJ, Mitrovski PJ (2003) Choreonema (Corallinales, Rhodophyta): 18S rDNA phylogeny and resurrection of the Hapalidiaceae for the subfamilies Choreonematoideae, Austrolithoideae and Melobesioideae. J Phycol 39:988-998

Harvey AS, Woelkerling WJ, Millar AJK (2009) The genus Amphiroa (Lithophylloideae, Corallinaceae, Rhodophyta) from the temperate coasts of the Australian continent, including the newly described A. klochkovana. Phycologia 48:258-290

Hebert PDN, Cywinska A, Ball SL, DeWaard JR (2003) Biological identifications through DNA barcodes. Proc Biol Sci, Royal Soc (B) 270:313-321

Holmgren PK, Holmgren NH (1998) [continuously updated]. Index herbariorum: a global directory of public herbaria and associated staff. New York Botanical Garden's Virtual Herbarium. Available at: http://sweetgum.nybg.org/ih/

Irvine LM, Johansen HW (1994) Corallinoideae. In: Irvine LM, Chamberlain YM (eds) Seaweeds of the British Isles, vol 1 Rhodophyta. Part 2B Corallinales Hildenbrandiales. HMSO Books, The Natural History Museum, London, pp 37-57

Johansen HW (1971) Changes and additions to the articulated coralline flora of California. Phycologia 10:241-249

Johansen HW (1981) Coralline Algae, a first synthesis. CRC Press, Boca Raton

Johansen HW, Silva PC (1978) Janieae and Lithotricheae: two new tribes of articulated Corallinaceae (Rhodophyta). Phycologia $17: 413-417$

Johansen HW, Womersley HBS (1994) Jania (Corallinales Rhodophyta) in southern Australia. Aust Syst Bot 7:605-625

Johansen HW, Irvine LM, Webster AM (1973) Haliptilon squamatum (L.) comb. nov., a poorly known British coralline alga. Br Phycol J 8:212 
John DM, Prud'homme van Reine WF, Lawson GW, Kostermans TB, Price JH (2004) A taxonomic and geographical catalogue of the seaweeds of the western coast of Africa and adjacent islands. Beih Nova Hedwigia 127:1-339

Johnston CS (1969) Studies on the ecology and primary production of Canary Islands marine algae. Proc Int Seaweed Symp 6:213-222

Jorge D, González MN, Delgado E (1984) Macrofitobentos del litoral del Puerto de Las Nieves (Gran Canaria). Botanica Macaron 1213:111-122

Kim JH, Guiry MD, Oak JH, Choi DS, Kang SH, Chung H, Choi HG (2007) Phylogenetic relationships within the tribe Janieae (Corallinales, Rhodophyta) based on molecular and morphological data: a reappraisal of Jania. J Phycol 43:1310-1319

Kohlmeyer J (1967) Intertidal and phycophilous fungi from Tenerife (Canary Islands). Trans Br Mycol Soc 50:137-147

Kristiansen A, Nielsen R, Pedersen PM (1993) An annotated list of marine algae collected on Lanzarote Canary Islands January 1986. Cour ForschungsInst Senckenberg 159:93-102

Kützing FT (1841) Über die "Polypieres calcifères" des Lamouroux. In: Kützing FT (ed) Zu der öffentlichen Prüfung sämmtlicher Classen der Realschule zu Nordhausen.1841. Nordhausen, Realschule, pp 3-34

Kützing FT (1849) Species algarum. Brockhaus, Lipsiae [Leipzig]

Kützing FT (1858) Tabulae phycologicae oder Abbildungen der Tange, vol 8. Nordhausen

Lamarck JB (1815) Suite des polypiers corticifère. Mus Hist nat Paris 2:76-84, 157-164, 227-240

Lamouroux JVF (1816) Histoire des polypiers coralligènes flexibles vulgairement nommés zoophytes. De l'imprimerie de F, Poisson, Caen

Lamouroux JVF (1821) Exposition méthodique des genres de l'ordre des Polypiers. Veuve Agasse, Paris

Lemoine P (1924) Corallinacées du Moroc (1). Bull Sci nat Maroc 4:113-134

Lemoine P (1929) Melobésiées. Biol Meddr K danske Vidensk Skr 8:1-97

Levring T (1974) The marine algae of the archipelago of Madeira. Bolm Mus munic Funchal 28:5-111

Linnaeus C (1758) Systema naturae per regna tria naturae, vol 1. Stockholm

López Hernández M, Gil-Rodríguez MC (1981) Estudio de la vegetación ficologica del litoral comprendido entre Cabezo del Socorro y Montaña de la Mar, Güímar, Tenerife. Vieraea 11:141-170

McNeill J, Barrie FR, Burdet HM, Demoulin V, Hawksworth DL, Marhold K, Nicolson DHJ, Prado J, Rado J, Silva PC, Skog JE, Wiersema JH, Turland NJ (2006) International Code of Botanical Nomenclature (Vienna Code) adopted by the 17th International Botanical Congress Vienna, Austria, July 2005. Gantner Verlag, Ruggell, Liechtenstein. (Note: Regnum Vegetabile, vol 146)

Medina M, Haroun RJ (1993) Preliminary study on the dynamics of Cystoseira abies-marina populations in Tenerife (Canary Islands). Cour ForschungsInst Senckenberg 159:109-112

Montagne JFC (1846) Ordo I. Phyceae Fries. In: Durieu De Maisonneuve MC (ed) Durieu de Maissonneuve Flore d' Algérie. Cryptogamie. Première Partie. Imprimerie Royale, publiée par ordre du Gouvernement et avec le concours d'une Commission Académique, Paris, pp 1-197

Montañés MA, Reyes J, Sansón M (2003) La comunidad de epífitos de Zonaria tournefortii en el norte de Tenerife (islas Canarias): análisis florístico y comentarios sobre su epifauna. Vieraea 31:121-132

Moura CWN, Guimarães SMPB (2002) O gênero Cheilosporum (Decaisne) Zanardini (Corallinales, Rhodophyta) no litoral do Brasil. Rev bras Bôt 25:65-77

Muñoz E, Reyes J, Sansón M (2007) Descripción y cartografía de las comunidades bentónicas de Playa de San Marcos (Tenerife islas Canarias). Vieraea 35:93-108
Neto AI (1994) Checklist of the benthic marine macroalgae of the Azores. Arquipélago 12A:15-34

Neto AI (2000a) Ecology and dynamics of two intertidal algal communities on the littoral of the Island of São Miguel (Azores). Hydrobiologia 432:135-147

Neto AI (2000b) Observations on the biology and ecology of selectes macroalgae from the littoral of Sao Miguel (Acores). Bot Mar 43:483-498

Neto AI (2001) Macroalgal species diversity and biomass of subtidal communities of São Miguel (Azores). Helgol Mar Research $55: 101-111$

Neto AI, Tittley I (1995) Structure and zonation of algal turf communities on the Azores: a numerical approach. Bolm Mus munic Funchal Suppl 4:487-504

Neto AI, Cravo DC, Haroun RJ (2001) Checklist of the benthic marine plants of the Madeiran Archipelago. Bot Mar 44:391-414

Newton L (1931) A handbook of the British seaweeds. British Museum (Natural History), London

Norris JN, Johansen HW (1981) Articulated coralline algae of the Gulf of California México I: Amphiroa Lamouroux. Smithson Contr Mar Sci 9:i-iii + (1) + 1-29

Otero-Schmitt J (1993) Some local patterns of zonation of benthic marine flora and fauna in Sal. Santiago. S. Vicente and Brava (Cape Verde Islands). Cour ForschungsInst Senckenberg 159:45-52

Otero-Schmitt J, Sanjuan A (1992) Epibiotic seaweeds of the Cape Verde Islands. Bot Mar 35:379-390

Palminha F (1957) Sobre a existencia de Lithophyllum tortuosum (Esper.) Foslie (= Tenarea tortuosa (Esper.) Lem.) nos Açores. Bol Soc Port Ciênc Nat 22:61-67

Pérez-Cirera JL (1975) Catálogo florístico de las algas bentónicas de la Ría de Corme y Lage, NO. de España. Anales Inst Bot Cavanilles 32:5-87

Piccone A (1884) Croceira del Corsaro alle isole Madera e Canarie del capitano Enrico d'Albertis. Alghe. Nuovo G bot Ital 16:1-60

Piccone A (1886) Alghe del viaggio di circumnavigazione della Vettor Pisani. Tipografia del Reale Istituto Sordo-Muti, Genova

Piccone A (1889) Alghe della Crociera del alle Azzorre. Nuovo G bot Ital Nuovo G bot Ital 21:171-214

Pinedo S, Sansón M, Afonso-Carrillo J (1992) Algas marinas bentónicas de Puerto de la Cruz (antes Puerto Orotava) Tenerife (Islas Canarias). Vieraea 21:29-60

Porter DM (1987) Darwin's notes on Beagle plants. Bull Br Mus nat Hist (Bot) 14:145-233

Price JH, John DM, Lawson GW (1986) Seaweeds of the western coast of tropical Africa and adjacents islands: a critical assessment. IV Rhodophyta (Florideae) 1. Genera A-F. Bull Br Mus nat Hist (Bot) 15:1-122

Price JH, John DM, Lawson GW (1992) Seaweeds of the western coast of tropical Africa and adjacent islands: a critical assessment. IV. Rhodophyta (Florideae) 3. Genera H-K. Bull Br Mus nat Hist (Bot) 22:123-146

Prud'homme van Reine WF (1988) Phytogeography of seaweeds of the Azores. Helgoländer Meeresunters 42:165-185

Prud'homme van Reine WF, Haroun RJ, Audiffred PAJ (1994) A reinvestigation of Macaronesian seaweeds as studied by A. Piccone with remarks on those studied by A. Grunow. Nova Hedwigia 58:67-121

Reyes J, Afonso-Carrillo J (1993) Morphology and anatomy of Mesophyllum canariense (Corallinaceae Rhodophyta) from the Canary Islands. Cour ForschungsInst Senckenberg 159:127-132

Reyes J, Sansón M (1991) Adiciones a la flora marina de la isla de El Hierro (Islas Canarias). Vieraea 20:71-81

Reyes J, Ocaña O, Sansón M, Brito A (2000) Descripción de comunidades bentónicas infralitorales en la Reserva Marina de La Graciosa e islotes del Norte de Lanzarote (islas Canarias). Vieraea 28:137-154 
Rojas-González B, Afonso-Carrillo J (2000) Morfología y distribución de Boergeseniella fructiculosa en las islas Canarias (Rhodophyta Rhodomelaceae). Vieraea 28:127-136

Rojas-González B, Afonso-Carrillo J (2002a) Morfología y distribución de Lophosiphonia cristata y L.reptabunda en las islas Canarias (Rhodophyta Rhodomelaceae). Vieraea 30:31-44

Rojas-González B, Afonso-Carrillo J (2002b) Notas corológicas sobre algas marinas de las islas Canarias: adiciones a la flora marina de El Hierro. Vieraea 30:99-107

Rojas-González B, Afonso-Carrillo J (2004) Morfología y distribución de Dipterosiphonia dendritica, D. rigens y D. reversa en las islas Canarias (Rhodophyta Rhodomelaceae). Vieraea 32:135-150

Rosas-Alquicira EF, Riosmena-Rodríguez R, Neto AI (2010) The lectotypification and status of Amphiroa cryptarthrodia (Lithophylloideae, Corallinales). Phycol Res (in press)

Sangil C, Sansón M, Afonso-Carrillo J (2003a) Algas marinas de La Palma (islas Canarias): novedades florísticas y catálogo insular. Vieraea 31:83-119

Sangil C, Afonso-Carrillo J, Sansón M (2003b) Zonación del fitobentos en el litoral sureste y adiciones a la flora marina de La Palma (Islas Canarias). Rev Acad Canar Cienc 15:310-319

Sangil C, Afonso-Carrillo J, Sansón M (2004) Zonación del fitobentos en el litoral Noroeste de La Palma (Islas Canarias). Rev Acad Canar Cienc 16:75-90

Sangil C, Sansón M, Afonso-Carrillo J (2005) Comunidades de algas esciáfilas en charcos eulitorales (La Palma, islas Canarias). Vieraea 33:323-333

Sansón M, Reyes J, Afonso-Carrillo J (1991) Contribution to the seaweed flora of the Canary Islands: new records of Florideophyceae. Bot Mar 34:527-536

Santos Guerra A (1972) Contribución al estudio de la flora de la isla de La Gomera. Vieraea 1:86-102

Santos Guerra A, Acuña Gonzalez A, Wildpret de la Torre W (1970) Contribución al estudio de la flora marina de la isla de La Palma. Cuad Bot Canaria 9:20-29

Sauvageau C (1912) A propos des Cystoseira de Banyuls et Guéthary. Bull Stn Biol Arcachon 14:133-556

Schmidt OC (1929a) Die marine Vegetation der Azoren (Vorläufiger Bericht.). Hedwigia 68:327-346

Schmidt OC (1929b) Beiträge zur Kenntnis der Meeresalgen der Azoren II. Hedwigia 69:165-172

Schmidt OC (1931) Die marine Vegetation der Azoren in ihren Grundzügen dargestellt. Bibliotheca Bot 24:1-116

Schneider CW, Searles RB (1991) Seaweeds of the southeastern United States. Cape Hatteras to Cape Canaveral. Duke University Press, Durham

Seoane-Camba J (1965) Estudios sobre las algas bentónicas en la costa sur de la Península Ibérica (litoral de Cadiz). Investigación pesq 29:3-216

Silva PC, Basson PW, Moe RL (1996) Catalogue of the benthic marine algae of the Indian Ocean. Univ Calif Publs in Bot 79:1-1259

Sonder G (1845) Nova algarum genera et species, quas in itinere ad oras occidentales Novae Hollandiae, collegit L. Priess, Ph. Dr. Botanische Zeitung 3:49-57

South GR, Tittley I (1986) A checklist and distributional index of the benthic marine algae of the North Atlantic Ocean. Huntsman Marine Laboratory and British Museum (Natural History), St. Andrews and London

Stafleu FA, Cowan RS (1988) Taxonomic Literature, vol. VII: W-Z. Bohn Scheltema and Holkema, Utrecht, The Netherlands

Stengenga H, Bolton JJ, Anderson RJ (1997) Seaweed of the south African west coast. Contr Bolus Herbarium 18:1-655

Taylor WR (1960) Marine algae of the Eastern Tropical and Subtropical coasts of the Americas. University of Michigan Press, Ann Arbor
Tittley I, Neto AI (2000) A provisional classification of algal characterised rocky shore biotopes in the Azores. Hydrobiologia 440:19-25

Tittley I, Neto AI (2005) The marine algal (seaweed) flora of the Azores: additions and amendments. Bot Mar 48:248-255

Tittley I, Neto AI (1994) Expedition Azores 1989. Benthic marine algae (seaweeds) record from Faial and Pico. Arquipélago 12A:1-13

Tittley I, Neto AI, Farnham WF (1998) Marine algae of the island of Flores Azores: ecology and floristics. Bolm Mus munic Funchal 5:463-479

Toste MF, Parente MI, Neto AI, Fletcher RL (2003) Life history of Colpomenia sinuosa (Scytosiphonaceae, Phaeophyceae) in the Azores. J Phycol 39:1268-1274

Tuya F, Haroun RJ (2006) Spatial patterns and response to wave exposure of shallow water algal assemblages across the Canarian Archipelago: a multi-scaled approach. Mar Ecol Prog Ser 311:15-28

Vickers A (1896) Contribution a la flore algologiques des Canaries. Annls Sci nat (Bot), Ser 4:293-306

Viera-Rodríguez MA (1987) Contribución al estudio de la flórula bentónica de la isla de La Graciosa Canarias. Vieraea 17:237-259

Viera-Rodríguez MA, Wildpret de la Torre W (1986) Contribución al estudio de la vegetación bentónica de la isla de La Graciosa. Canarias. Vieraea 16:211-231

Viera-Rodríguez MA, Gil-Rodríguez MC, Audiffred PAJ, Prud'homme Van Reine WF, Haroun-Tabraue R, Wildpret de la Torre W (1987) Contribución al estudio de la flórula bentónica del islote de Montaña Clara. Canarias. Vieraea 17:271-279

Villena-Balsa M, Afonso-Carrillo J, Wildpret de la Torre W (1987) Morfología, estructura y reproducción de una especie epífita del género Jania (Corallinaceae, Rhodophyta) de las Islas Canarias. Vieraea 17:19-42

Walker RH, Brodie J, Russell S, Irvine LM, Orfanidis S (2009) Biodiversity of coralline algae in the Northeastern Atlantic including Corallina caespitosa sp. nov. (Corallinoideae, Rhodophyta). J Phycol 45:287-297

Wallenstein FM, Neto AI (2006) Intertidal rocky shore biotopes of the Azores: a quantitative approach. Helgol Mar Res 60:196-206

Weber-van Bosse A (1904) Corallinaea verae of the Malay Archipelago II. In: Weber-van Bosse A, Foslie M (eds) The Corallinaceae of the Siboga-Expedition, vol 61. Siboga-Expeditie: ...Uitkomsten op Zoologish, Botanosch, Oceanographisch en Geologisch Gebied... Monographie, pp 78-110

Weisscher FCM (1982) Marine algae from Ilhéu de For a (Salvage Island) (Cancap-Project Contributions No. 13). Bolm Mus munic Funchal 34:23-34

Weisscher FCM (1983) Marine algae from Selvagem Pequena (Salvage Island). Bolm Mus munic Funchal 35:41-80

Woelkerling WJ, Nelson WA (2004) A baseline summary and analysis of the taxonomic biodiversity of Coralline red algae (Corallinales Rhodophyta) recorded from the New Zealand region. Cryptogamie Algol 25:39-106

Woelkerling WJ, Sartoni G, Boddi S (2002) Paulsilvella huveorum gen. et sp. nov. (Corallinaceae, Rhodophyta) from the Holocene of Somalia and Kenya, with a reassessment of Lithothrix antiqua from the Late Pleistocene of Mauritius. Phycologia 41:358-373

Woelkerling WJ, Millar AJK, Harvey A, Baba M (2008) Recognition of Pachyarthron and Bossiella as distinct genera in the Corallinaceae, subfamily Corallinoideae (Coarllinales, Rhodophyta). Phycologia 47:265-293

Womersley HBS, Johansen HW (1996) Subfamily Corallinoideae. In: Womersley HBS (ed) The Marine benthic flora of Southern Australia-Part IIIB. Gracilariales Rhodymeniales Corallinales 
and Bonnemaisoniales. Canberra Australian Biological Resources Study, Australia, pp 288-317

Yendo K (1905) A revised list of Corallinae. J Coll Sci Imp Univ Tokyo 20:1-46

Yoshida T (1998) Marine algae of Japan. Uchida Rokakuho Publishing, Tokyo
Zanardini G (1840) (Lettera) alla direzione della biblioteca Italiana. Biblioteca Ital Milano 96:131-137

Zanardini G (1844) Corallinee. Encicl. Ital. (Venezia:Tasso) 6:10131036 